KOÇ UNIVERSITY-TÜSİAD ECONOMIC RESEARCH FORUM

WORKING PAPER SERIES

\title{
NEGATIVE INTEREST RATES, EXCESS LIQUIDITY AND RETAIL DEPOSITS: BANKS' REACTION TO UNCONVENTIONAL MONETARY POLICY IN THE EURO AREA
}

\author{
Selva Demiralp \\ Jens Eisenschmidt \\ Thomas Vlassopoulos
}

Working Paper 1910

May 2021

This Working Paper is issued under the supervision of the ERF Directorate. Any opinions expressed here are those of the author(s) and not those of the Koç University-TÜSİAD Economic Research Forum. It is circulated for discussion and comment purposes and has not been subject to review by referees.

KOÇ UNIVERSITY-TÜSİAD ECONOMIC RESEARCH FORUM

Rumelifeneri Yolu 34450 Sarıer/Istanbul 


\title{
Negative interest rates, excess liquidity and retail deposits: Banks' reaction to unconventional monetary policy in the euro area ${ }^{1}$
}

\author{
Selva Demiralp ${ }^{\mathrm{a}}$ \\ Jens Eisenschmidt ${ }^{\mathrm{b}, 2}$ \\ Thomas Vlassopoulos ${ }^{\mathbf{b}}$ \\ ${ }^{\text {a }}$ Department of Economics, Koç University, Istanbul, Turkey \\ ${ }^{\mathrm{b}}$ European Central Bank, Frankfurt, Germany
}

\begin{abstract}
Negative interest rate policy (NIRP) is associated with a particular friction. The remuneration of banks' retail deposits tends to be floored at zero, which limits the transmission of policy rate cuts to bank funding costs. We investigate whether this friction affects banks' reactions under NIRP compared to a standard rate cut in the euro area. We argue that reliance on retail deposit funding and the level of excess liquidity holdings may increase banks' responsiveness to NIRP. We find evidence that banks highly exposed to NIRP tend to grant more loans, i.e. NIRP is indeed expansionary for the levels of interest rates seen in the euro area so far. This confirms studies pointing to higher risk taking by banks under NIRP and sheds some new light on results that associate NIRP with a contraction in bank loans, albeit in specific market segments. We are the first to document the importance of banks' excess liquidity holdings for the effectiveness of NIRP, pointing to a strong complementarity of NIRP with central bank liquidity injections, e.g. via asset purchases.
\end{abstract}

Keywords: Negative rates, bank balance sheets, monetary transmission mechanism JEL Classifications: E43, E52, G11, G21

\footnotetext{
${ }^{1}$ The views expressed are those of the authors and do not necessarily reflect those of the ECB. We are grateful for comments from S. Reynard, A. Nobili, F. Smets and an anonymous referee, as well as from seminar participants at the SNB, UC Irvine, EEA and AEA Annual Meetings and the sixth BdI-CEPR conference on Money, Banking and Finance. L. Ferrante, L. Pagenhardt, I. Salcher, M. Souchier, J. Worlidge, G. Sciacovelli, and B. Bjai provided excellent research assistance.

${ }^{2}$ Corresponding author.

E-mail addresses: sdemiralp@ku.edu.tr, Jens.Eisenschmidt@ecb.int, Thomas.Vlassopoulos@ecb.int
} 


\section{Introduction}

In June 2014, the European Central Bank (ECB) cut its deposit facility rate (DFR) to negative territory, an unprecedented move as no other major central bank had used negative rates before. ${ }^{3}$ The ECB's decision to introduce negative rates was part of a monetary stimulus package aimed at fending off deflationary risks in a situation in which policy rates had reached zero. More generally, decreasing levels of equilibrium interest rates all around the world and declining trend growth rates have elevated the practical relevance of this new monetary policy tool, as monetary policy is more likely than in the past to operate in the vicinity of the lower bound of policy rates. Kiley and Roberts (2017) note that the "zero lower bound" could, in the future, be binding up to 40 percent of the time. In view of this, the assessment of the effectiveness of negative interest rate policy (NIRP), which is the topic of this paper, is of high importance for policy makers and academics all around the world. In this paper, we show that NIRP has been expansionary in the euro area by encouraging banks to increase their lending activity.

Rate cuts resulting in negative policy rates are unlikely to operate in the same fashion as conventional rate cuts because banks may not be able to charge their retail customers negative rates on their deposits. Banks' inability to adjust a part of their funding costs may be due to the forces of competition - in combination with the high regulatory value of retail deposits due to their stability - as well as the existence of banknotes, which offer an alternative store of value with a yield of zero. Therefore, NIRP should have an impact on banks' profitability as the remuneration of banks' assets declines as a consequence of NIRP while a significant part of their funding costs remains unchanged, leading to declining intermediation margins. In line with this argument, several papers in the literature

\footnotetext{
${ }^{3}$ This followed a similar decision by the Danish central bank (Danmarks Nationalbank) in July 2012. Subsequently, the Swiss National Bank and the Swedish Riskbank introduced negative policy rates in December 2014 and February 2015, respectively, see Jackson (2015). The Bank of Japan followed suit in January 2016.
} 
(Brunnermeier and Koby; 2017, Eggertsson et al.,2017) come to the conclusion that negative rates are either clearly contractionary or that they could at least potentially be contractionary, as they may induce banks to cut their lending, increase lending rates or both.

In principle, an alternative reaction to the compression of bank interest margins is also possible. Banks may attempt to tilt the composition of their balance sheets towards higheryielding assets in order to reinstate the average return they earn across their entire portfolio. This can be viewed as a particular version of the standard portfolio rebalancing mechanism that is typically associated with non-standard monetary policy measures, such as quantitative easing (e.g. Krishnamurthy and Vissing-Jorgensen, 2011). To the extent that this rebalancing results in the shifting of portfolios towards loans to the real economy, it will have expansionary effects. Whether this mechanism dominates the contractionary one described above is essentially an empirical question and this paper sets out to answer it for the euro area. Using confidential bank-level data covering around $70 \%$ of main assets and $80 \%$ of total loans of euro area banks in a sample running from January 2010 until September 2017, we find that NIRP has been expansionary by inducing highly-exposed banks to increase their lending activity in an effort to mitigate the adverse impact of NIRP on their profitability.

We contribute to the literature on the effectiveness of NIRP by highlighting the role of excess liquidity (i.e. central bank reserves in excess of banks' reserve requirements, EL henceforth) in the transmission mechanism. Most of the literature uses the variation in retail deposit intensity to identify the effects of NIRP on banks. The identification of NIRP is a challenging task in the simultaneous presence of other confounding measures, like the ECB's asset purchase programme (APP), which - just like NIRP - flatten the yield curve and adversely affect banks' net interest margins. We show that by adding banks' EL position, we can further increase the confidence in the identification of the effects of NIRP on banks. Bank-specific EL is a critical variable to complement retail deposit intensity for the 
identification of the impact of NIRP. This is because banks' costs of holding EL increase proportionally to their retail deposit intensity and these costs are uniquely related to NIRP and not to any other concurrent monetary policy measure. Bank-specific EL thus captures banks' heterogeneous treatment by NIRP and neglecting this component and focusing only on the retail deposit intensity might not adequately capture the true impact of NIRP on bank balance sheets.

Consequently, we exploit the interaction of the cross-sectional variation of retail deposit intensity and banks' EL holdings for the identification of effects of NIRP on euro area banks, allowing us to better isolate the effects of NIRP from other policy easing measures. Another way of looking at our identification is that it combines two crucial elements in banks' reaction to NIRP: the motive and the opportunity to react. Banks are primarily motivated by the squeeze of their intermediation margins, captured by their retail deposit intensity. The availability of negative-yielding assets in the form of EL that can quickly be redeployed towards higher-yielding uses affords them a specific opportunity to address the squeeze on their margins. The joint presence of the two - motive and opportunity - is necessary for this transmission channel of NIRP to be activated. This points to an important complementarity of NIRP with other easing measures that inject central bank liquidity into the banking system, e.g. asset purchase programmes: EL injected by the central bank activates expansionary effects of NIRP over and above what could be expected from the rate cut alone. We find that within the group of banks with high deposit intensity, higher levels of EL are associated with more loan issuance during NIRP.

Our identification assumption relies on (i) low EL banks not being affected by NIRP and (ii) high EL banks remaining in that category indefinetely such that low EL banks indeed provide a valid counterfactual for high EL banks during NIRP. Regarding the former, to the extent that low EL banks are at least indirectly affected by the behavior of high EL banks, our 
identification weakens. Regarding the latter, while banks are able to change their exposure to EL at the margin, they are unable to do so at a sufficient scale and with a permanent effect. As a result, the relative position of banks in the EL distribution is, by and large, preserved, even in the presence of banks' adjustment to NIRP. The best way to think about this is to consider what banks can do about their EL position as a "second order adjustment" at the margin. It still improves their overall situation, which motivates them to adjust their EL. Meanwhile, a bank's exposure to the EL that is added to the system, predominantly through asset purchases within our sample period, is fundamentally determined by its place in the financial system.

To illustrate the above point with an example, consider a bank that has a deposit collection franchise and many offices around the country. This bank will always receive a certain proportion of the inflows of (excess) liquidity in every period in the form of customer deposits. It cannot change its position within the financial system at short notice. In fact, it will not do so absent a large and persistent shock because this position represents its business model choice. There are large fixed costs associated with changing this business model choice. ${ }^{4}$ Structural inflows of EL, owing to a banks' position in the financial network, are of "first order" compared with what the bank can do to adjust its EL position. Our estimates serve to illustrate this point: The effect of NIRP through EL on banks' loan creation lies between 12 percent and 15 percent (depending on the model) of the observed quarterly lending by high deposit banks. The average EL inflow for high deposit banks during NIRP was 744 million euros per quarter while the average loan flow for this group of banks was 106.9 million euros per quarter, with loan flows explained by banks' EL holdings ranging between 12 and 16 million euros. This clearly illustrates the order of magnitude difference in

\footnotetext{
${ }^{4} \mathrm{We}$ formally test this intuition in section 6.3. Using dynamic clustering methods (dynamic k-means) and allowing for banks' switching business models, we establish, in line with the findings of Lucas et al. (2019), that banks in our sample are unlikely to change their business model, at least during the years covered by our sample.
} 
the estimated EL adjustment through loans to the quarterly EL inflows of the average high deposit bank in our sample.

Our findings appear to contrast some earlier papers, e.g. Heider et al. (2019), which find that banks that are more reliant on deposit funding reduce their (syndicated) loans during NIRP. Our different result, however, reflects the much wider coverage of our sample. Syndicated loans account for only $3 \%$ of euro area loans, whereas our sample includes the vast majority of euro area bank loans, including syndicated loans. For the group of banks that are active in the syndicated loan market, we qualitatively replicate the findings reported in Heider et al. (2019). Furthermore, we show that their findings are preserved for an extended sample that includes two more years of data until the end of 2017. This appears to be an important result in light of the recent contributions that found evidence for a reversal of the expansionary impact of NIRP in later periods (see Arce et al. 2018). We then move beyond this result, in line with our conceptual discussion on the channels available to banks to reduce their EL holdings (section 3).We show that high deposit banks active in the syndicated loan market do in fact adjust to NIRP, just not by granting more loans, but instead by purchasing more securities. This adjustment strategy appears in line with their comparative advantage, as the banks we identify as being active in the syndicated loan market are often banks with larger security holdings.

Once we turn to the broader sample of banks and loans, the negative and significant impact of NIRP on bank loans observed in the syndicated loan market disappears. When we further add EL to complement our identification, we obtain a positive and significant effect associated with NIRP on bank lending. Notably, our result is fully in line with survey evidence gathered from euro area banks by the ECB in its bank lending survey: banks regularly report that NIRP has induced them to grant more loans (ECB, 2020). 
Our paper pays particular attention to the role of EL, which provides stronger incentives for banks to engage in portfolio rebalancing during NIRP. This allows us to identify a channel that is not explicitly considered in most of the earlier literature. ${ }^{5}$ Our findings are consistent with Lopez et al. (2018) who establish stylized facts for banks' reaction to NIRP and show that high deposit banks give out more loans and reduce their central bank reserves during NIRP. Focusing on French banks and using a confidential dataset, Grandi and Guille (2020) also find that NIRP is associated with an increase in lending by high deposit banks. An analogous result is obtained for Japanese banks by Hong and Kandrac (2018). In line with the bulk of the literature (Heider et al, 2019, Bubeck et al., 2020, Bottero et al., 2019), we find support for the result that banks highly exposed to NIRP take on more risk, as they effectively convert a risk-less asset - EL - into a risky one - bank loans. Moreover, our results in this respect are also consistent with Nucera et al. (2017) as well as Boungou (2020), who find that risk-taking under NIRP depends on individual bank characteristics. Finally, our findings are also consistent with the theoretical framework developed by Ulate (2021), where it is found that monetary policy is 60 to 90 percent as effective under NIRP, where the efficacy is higher in the euro area.

We start the paper with a discussion of the particular friction associated with NIRP and why banks may operate differently under these circumstances. We then discuss the channels that banks may use to adjust their balance sheets in the face of negative rates. Section 4 describes our empirical strategy and approach to identification and section 5 reports our results. In section 6 , we consider several robustness checks and section 7 concludes.

\footnotetext{
${ }^{5}$ An exception is Altavilla et al. (2018) who also use EL as an explanatory variable in one of their robustness checks. Bottero et al. (2019) consider a similar channel but do not use EL because their sample of banks is not suitable for this type of identification. Basten and Mariathasan (2018) also exploit exposure to EL in an indirect way by focusing on the exemption threshold for reserves not subject to a negative remuneration.
} 


\section{Are negative rates special?}

\subsection{The pass-through of negative interest rates to financial market rates and retail deposit rates in the euro area}

The ECB introduced negative rates in June 2014 by lowering the DFR to -0.10 percent. Further rate cuts followed (September 2014, December 2015, March 2016 and September 2019) bringing the rate on the ECB's deposit facility to -0.50 percent. $^{6}$

The initial transmission of DFR cuts to short-term money market rates took longer than usual, likely due to the time needed by financial market participants to adjust to the new environment (e.g. changes to IT systems, legal documentation). Nevertheless, all rate cuts after May 2015 did pass through immediately to short-term interest rates (Figure 1). The overnight index swap (OIS) curve was in negative territory for maturities of up to four years and short-term government bonds of the highest credit quality were trading at yields well below the DFR, demonstrating that the pass-through of negative rates was eventually complete.

A different picture emerges when we look at rates paid by banks for deposits of households and non-financial corporations (NFC) (Figure 2). Comparing the distribution of deposit rates across a representative sample of euro area banks in June 2014 and September 2017, it is clear that both types of deposit rates have declined during the NIRP period, with both distributions having most of their mass at zero at the end of our sample period. This "piling up" of deposit rates at zero suggests the existence of a zero lower bound for bank deposits, although there are some banks that do report rates below zero for their household and, more prominently, NFC deposits. By further zooming in on the case of German banks,

\footnotetext{
${ }^{6}$ The negative rate is not only applied to recourse to the deposit facility but to all parts of banks' current accounts with the Eurosystem in excess of their reserve requirements. The same applies to other potential "loopholes", e.g. the remuneration of government deposits as well as deposits in the context of reserve management services offered by the ECB were also lowered in the process to (at least) $-0.50 \%$. As our sample ends in September 2017, we only cover the cuts until $-0.40 \%$.
} 
Eisenschmidt and Smets (2019) show that the zero lower bound on bank deposits only holds for retail deposits, whereas Altavilla et al. (2019) document that firms are indeed exposed to negative deposit rates and this induces them to increase their investment spending. Potential explanations for the existence of a zero lower bound on retail deposits include the existence of banknotes that offer a way to avoid any negative rates on deposits, in combination with low switching costs of households who normally hold relatively small-sized deposits. From the banks' perspective, competition in the deposit market combined with the regulatory and commercial value of deposits due to their stickiness as well as costs associated with switching to a different business or funding model imply that they are reticent to lower retail deposits rates below zero (see Drechsler et al., 2017 and 2020, for a discussion on the value of retail deposits for banks in the US).

\subsection{The transmission mechanism of monetary policy under NIRP}

Banks are important for the transmission of monetary policy to the economy, especially for bank-centred financial systems such as the one in the euro area. Changes in monetary policy rates trigger reactions in bank behaviour but the theoretical and empirical literature studying these reactions typically refers to environments where policy rates are adjusted (and remain) in positive territory. It is unclear whether these mechanisms carry over when policy interest rates are reduced to levels below zero.

According to the standard interest rate channel, a change in the policy rate is transmitted to deposit and loan rates through the banking system. However, the effective zero lower bound on retail deposits implies that a significant part of banks' funding cannot be repriced further once this threshold is reached, which could induce a change in the standard transmission mechanism. ${ }^{7}$ The presence of NIRP imparts some heterogeneity in the banking

\footnotetext{
${ }^{7}$ The "specialness" of NIRP, at least in a temporary sense, may also derive from a range of institutional features of the financial system. In some jurisdictions there may be legal restrictions to the application of negative rates to bank customers or at least uncertainty regarding the legal standing of such arrangements. Some financial contracts (e.g. money market funds or floating rate notes) may not foresee the possibility of payments from the
} 
system as it prevents banks with high reliance on retail deposits from fully adjusting their funding costs. The literature on interest rate pass-through for the euro area finds evidence of imperfect pass-through onto loan rates (see Berke et al., 2013; Hristov et al., 2014; Gambacorta et al., 2015; Avouyi-Dovi et al., 2017; Horvath et al., 2018). The resulting squeeze in profit margins may impair the standard interest rate channel because high deposit banks might start raising loan rates instead of lowering them in response to a policy easing to protect their profit margins. Heider et al. (2019) investigate this possibility and note that there is no evidence of higher loan rates charged by high deposit banks in the euro area. Meanwhile Basten and Mariathasan (2018) and Eggertsson et al. (2017) provide evidence of an increase in fees and lending rates following rate cuts into negative territory in Switzerland and Sweden. Lopez et al. (2018) find that banks that rely more on deposit funding are more vulnerable to losses in interest income when interest rates are negative because they are less capable of raising non-interest income.

According to the bank lending channel, expansionary monetary policy measures increase banks' willingness to provide loans (Bernanke and Blinder, 1998). Several papers support the notion that the bank-lending channel remains intact under NIRP (e.g. Albertazzi et al., 2017; Bräuning and Wu, 2017; Basten and Mariathasan, 2018) while others argue that the bank lending channel is less effective in a low interest rate environment (Borio and Gambacorta, 2017) or that it breaks down once the zero bound on deposits is reached (Eggertsson et al., 2017). We argue that this channel may in fact be strengthened by NIRP for

lender to the borrower (see Witmer and Yang, 2015) and in any case the logistics of collecting interest payments from holders of securities can be intractable. Similarly, some IT systems may not be designed to cope with negative rates. Other examples of possible institutional restrictions include the tax treatment of negative interest rate income, which is often not symmetric to the treatment of positive interest rate income, e.g. payments triggered by negative interest rates may not be tax deductible, while positive interest rate income is generally taxable. Finally, internal risk management practices and rules in banks may in some cases prevent transactions that imply a loss on principal, such as holding negatively remunerated central bank reserves. While some of these institutional features may be adapted in light of the introduction of NIRP, such changes are typically implemented slowly. 
two reasons. Firstly, the charge on EL may motivate banks to extend more loans in an effort to reduce their reserve holdings, thereby avoiding it. Secondly, from the perspective of depositors, the zero lower bound on deposit rates leads to a decrease in the opportunity cost of holding retail deposits and increases the demand for such deposits. Banks may respond to this increased deposit funding by issuing more loans. Thus, while NIRP reduces the ability of banks to pass on lower rates to their borrowers and may thus reduce the effectiveness of the interest rate channel, the policy may amplify the bank lending channel by increasing the cost of holding EL, in particular for banks with a high share of retail deposit funding on their balance sheet. ${ }^{8}$ The identification strategy employed in this paper is based on this idea.

The exchange of very safe assets such as central bank reserves for riskier assets like loans and bonds can also be seen through the lens of the risk-taking channel, which emphasises the role of risk perceptions and risk tolerance (Borio and Zhu, 2008; Adrian and Shin, 2009; Jimenez et al., 2014; Dell'Ariccia et al., 2017). The increase in asset prices and collateral values prompted by lower policy rates can boost banks' capacity and willingness to take on more risk. For instance, banks may rely on risk measures that are based on market equity prices, such as expected default frequencies, and make use of Value-at-Risk frameworks for their asset-liability management, all of which are likely to allow higher risk taking in an environment of lower rates. Moreover, "sticky" rate-of-return targets defined in nominal terms can prompt a "search for yield" effect when interest rates are reduced, which necessitates higher risk tolerance. In fact, the promotion of portfolio rebalancing by encouraging lenders to invest in riskier assets when the returns on safer assets decline is

\footnotetext{
${ }^{8}$ It is an interesting question what affected banks will do to grant more loans and the answer to this question depends crucially on the market structure in the relevant segments of the loan market. In the euro area, loan markets are characterised by monopolistic competition and banks can increase their market share by lowering their loan rates and/or adjusting their risk thresholds and lower their fees and commissions. Such adjustment may be at work without the bank necessarily being forced to lower its loan rates because of direct price competition from banks with more favourable funding model. At the same time, our analysis does not rule out the presence of such forces.
} 
considered to be one objective of quantitative easing policies (Aramonte et al., 2015; Heider el al., 2019). This channel is likely to be further reinforced by the existence of negative rates.

While NIRP may stimulate bank balance sheet adjustment due to charges on EL and increased risk taking, there might be "tipping points" beyond which banks cannot tolerate further squeezes in their margins and adopt different strategies (Bech and Malkhozov, 2016). This argument is further taken up in Brunnermeier and Koby (2017) who argue that below some level of the policy rate (which is not necessarily zero) further reductions can in fact be contractionary owing to the financial instability they induce and the ensuing contractionary effects on bank lending. Arce et al. (2018) test this argument for Spanish banks and note that weakly capitalised banks curtailed their lending in the later part of their sample. As the theory incorporates offsetting factors, determining the net impact of NIRP on bank lending is ultimately an empirical question, to which we turn in section 4 .

\section{Strategies for bank balance sheet adjustments under NIRP}

If banks reduce their EL holdings to avoid the additional costs during NIRP, this adjustment process normally involves changes to other items on the banks' balance sheets. The general adjustment channels that we consider are depicted in Figure 3. Starting from a stylized balance sheet illustrated on the upper left panel, we consider adjustments on the asset side in the form of loan creation (lower right) ${ }^{9}$ or the acquisition of other assets, such as securities (lower left), financed by lower EL holdings. In addition, banks may consider balance sheet reduction (non-roll over of bank funding) illustrated on the upper right panel. We test for the presence of these three channels in the empirical analysis.

There is one important caveat regarding the potential for banks' balance sheet adjustments to reduce their holdings of EL: banks cannot change aggregate EL (at least not in

\footnotetext{
${ }^{9}$ Banks cannot lend out EL to non-banks, so in a narrow sense, the depicted adjustment channel would only work if the loans considered were interbank loans. At the same time, granting a loan can be seen as an activation strategy that increases the probability that part of a banks' EL leaves the bank in the form of interbank payments stipulated by recipients of the loan made by the bank.
} 
the short run). While any individual bank can plausibly expect that a strategy to reduce its EL will be successful, it will not work for the system as a whole (see also section 4.2 in Ryan and Whelan, 2019). Some banks will inevitably end up with EL holdings. The system as a whole can only reduce EL by repaying borrowing from the Eurosystem or by acquiring banknotes. Typically, however, banks do not borrow from the Eurosystem in order to hold funds at the deposit facility and earn a negative spread. ${ }^{10}$ Instead, banks borrow to cover liquidity needs (e.g. in the weekly refinancing operations with a maturity of one week) or even funding needs (e.g. in the refinancing operations with long maturities like the long-term refinancing operations (LTROs)). This implies that the funds borrowed are paid out to other banks within the closed system in which central bank reserves circulate. Moreover, in a context where the central bank is engaging in large-scale asset purchases, most of the EL in the system is not actively generated by banks' borrowing from the central bank but passively received when central bank asset purchases are settled. In both cases, the banks that end up holding the EL are different from the ones that have borrowed from the Eurosystem because banks that hold EL do so primarily for reasons that are linked to their role and position in the financial system. ${ }^{11}$ Overall, there is very limited scope for individual bank EL to be reduced by repaying borrowing from the central bank. ${ }^{12}$

\footnotetext{
${ }^{10}$ An exception refers to episodes of acute turmoil in money markets, when banks may for precautionary reasons choose to simultaneously borrow from the central bank and hold the funds borrowed with the central bank as liquidity buffers. Such episodes were observed in the early stages of the financial crisis. Such a situation was not, however, observed during the NIRP period covered by our sample.

${ }^{11}$ For example, a bank with high retail deposit intensity in its funding strategy will maintain some retail deposit generating infrastructure (a network of branches and offices) and it will be difficult for the bank to fully control the amount of retail deposits it takes in through this infrastructure.

${ }^{12}$ Prudential regulation also imposes constraints on banks' adjustment space as is reflected in a multitude of regulations that govern the possible evolution of a bank's balance sheet (e.g. capital needed for loans, liquidity regulations constraining the funding strategy and leverage ratios limiting balance sheet size expansion stemming from particular items). For example, a bank may be constrained in its ability to extend lending by binding capital requirements or by liquidity regulation in which the exchange of a high-quality liquid asset for a loan that does not qualify as such would have adverse implications for regulatory liquidity ratios.
} 


\section{Empirical strategy}

In line with the conceptual discussion in the previous section, our empirical analysis focuses on tracing out three possible bank balance sheet adjustments triggered by the introduction of NIRP: loan extension, acquisition of other assets, and decline in wholesale funding.

\subsection{Data}

We make use of a confidential dataset containing balance sheet data for 252 euro area banks at the monthly frequency. Because monthly data may be subject to more random volatility, we report the empirical results obtained using quarterly averages. Nevertheless, the results are highly robust to using the monthly frequency as well (not shown). The Eurosystem central banks collect the data with a view to reach a high degree of representativeness of the euro area banking sector, containing a broad range of banks of different sizes and business models from all euro area countries. Importantly, banks contained in the sample cover a large fraction of loans to the euro area economy (between $70 \%$ and $85 \%$ of all bank loans, depending on the country). We exclude banks from Cyprus and Greece because these banks were affected by domestic economic and banking crises during the period covered by our sample. We also exclude banks that are particularly affected by the ECB's APP, such as banks that are directly exposed to the implementation of Eurosystem asset purchases, ${ }^{13}$ banks handling large amounts of euro liquidity on behalf of non-euro entities (see Eisenschmidt et al., (2017)) or banks handling the cash leg of an APP transaction for non-euro area banks. For these banks, standard balance sheet adjustment channels described above are unlikely to be viable options, owing to their specific role in the implementation of the APP and the financial

\footnotetext{
${ }^{13}$ Banks affected by the APP typically display a strong co-movement of their main assets with their excess liquidity after March 2015, dwarfing other balance sheet changes. We exclude all those banks for which we observed an average EL ratio over main asset in excess of $10 \%$ over the APP period. In a second step, we manually checked all banks selected by that criterion to verify their close connection to the APP.
} 
system architecture more broadly. This leaves us with 196 banks with balance sheet data from 2010Q1 until 2017Q3.

\subsection{Identification}

The introduction and further roll-out of NIRP occurred in tandem with the announcement of other non-standard monetary policy measures by the ECB. In particular, the first reduction of the DFR to negative territory in June 2014 coincided with the announcement of the first wave of TLTROs. The next reduction of the DFR to -0.20 percent was decided in September 2014, together with the announcement of the asset-backed securities purchase programme (ABSPP) and the third covered bond purchase programme (CBPP3). The last two rate cuts in our sample, December 2015 and March 2016, coincided with extensions of the ECB's APP, which started in March 2015 and was broadly expected by financial markets as early as September 2014 .

This confluence of various policy measures can have a bearing on banks' decisions and thus renders the identification of the effects of NIRP based purely on the timing of its introduction problematic. For example, it is plausible to expect the APP to have induced significant portfolio rebalancing effects (Albertazzi et al., 2021). The availability of longterm funding at an attractive price through the TLTRO can also be expected to incentivise the acquisition of assets and more generally changes to banks' balance sheets as the targeting elements of this measure would be expected to spur increased lending in particular.

Against this backdrop, our identification of the impact of NIRP relies on the crosssectional variation of the two characteristics of the banks in our sample that are directly connected with NIRP: banks' retail deposit intensity and EL holdings. Bank's retail deposit intensity is the standard identification approach in the empirical literature on NIRP. We add banks' EL holdings to that standard identification, exploiting an additional variable capturing the heterogenous exposure of banks to NIRP. Considering the cross-sectional variation in 
these two characteristics jointly allows us to better identify effects that are exclusively linked to NIRP and not to any other concurrent monetary policy measure.

The volume of EL held by each bank is distinct and changes through time. Banks' EL holdings (and their expectations of the additional EL that they will receive in the future) define the direct costs of NIRP for banks. These costs translate into pressure for banks to adjust their balance sheets. Moreover, for a given level of EL, banks' incentives for balance sheet adjustment triggered by NIRP will differ depending on their exposure to retail deposits. In line with the discussion in section 2, we expect that banks that rely on traditional retail deposit funding to be more responsive to NIRP compared to banks that use funding options with a higher interest rate pass-through.

A prerequisite for using banks' EL holdings as an exposure variable is its exogeneity with respect to the treatment. To formally test this argument, we consider the EL ratio as the dependent variable in equation (1) and test whether being in the group of banks with high EL ratios prior to NIRP is the key determinant for the level of their EL ratio during NIRP.

$$
\begin{gathered}
\mathrm{EL}_{\mathrm{i}, \mathrm{t}}=\mathrm{T}_{\mathrm{t}}+\beta_{1} \text { Avg_EL }_{\mathrm{i}}+\beta_{2} \text { Retail Ratio }_{\mathrm{i}, \mathrm{t}-1}+\beta_{3} \text { Liquidity ratio }_{i, t-1} \\
+\beta_{4} \text { Leverage ratio }_{i, t-1}+\beta_{5} r_{i, t-1}^{\text {Loan }}+\varepsilon_{i t}
\end{gathered}
$$

where $E L_{i, t}=\frac{\text { Excess Liquidity }_{i, t}}{\text { Assets }_{i, t}}$, Avg_EL $_{\mathrm{i}}$ is the average EL ratio of bank $i$ in the year before

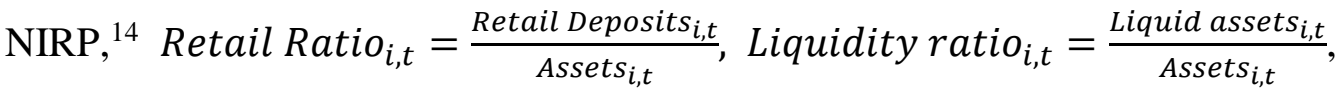
Leverage ratio $o_{i, t}=\frac{(\text { Capital }+ \text { Reserves })_{i, t}}{\text { Asset }_{i, t}}$, and $r_{i, t-1}^{\text {Loan }}$ is the composite loan rate.

Our identification assumption relies on high EL banks - based on average EL levels in the year before NIRP - remaining high EL banks under NIRP, i.e. that banks do not switch between categories such that low EL banks indeed provide a valid counterfactual for high EL

\footnotetext{
${ }^{14}$ The year before NIRP is defined as the interval from 2013.Q2 through 2014.Q2.
} 
banks during NIRP. Table A1.1 shows the regression results. We note that the coefficient associated with Avg_EL $L_{i}$ is highly significant and not significantly different from one, suggesting a one to one relationship between $\mathrm{Avg}_{-} \mathrm{EL}_{\mathrm{i}}-$ which is the average EL ratio in the year before NIRP- and future levels of EL. This finding strongly supports our identification assumption which posits that a bank's EL position is primarily a function of its place in the financial system and its business model. While banks can change their EL holdings somewhat, these changes are of second order relative to the fundamental determinants of banks' relative EL position.

As a further illustration for the stability of high EL levels within the group of high deposit banks, we classify banks that are in the top tercile based on their average retail deposit ratios in the year before NIRP as "highest deposit" banks. Within that group, we sort the banks based on their average EL ratios before and after NIRP. Figure 4 provides a scatterplot of each bank's EL ranking during pre-NIRP period against its ranking during NIRP period. We observe that the relative ranking of a particular bank with respect to its EL ratio before NIRP is highly correlated with its relative ranking after NIRP, fitting a regression line close to a 45-degree angle.

We conceptualise our identification strategy and its links to the literature in Figure 5, which is key to understanding our empirical approach. Figure 5 compares the balance sheets of two stylized bank funding models, considering only the elements relevant for our research question. Bank A is entirely funded by retail deposits and hence faces a zero lower bound in passing the policy rate changes onto deposit rates. Meanwhile Bank B is entirely funded in the wholesale market with complete interest rate pass-through ( $\mathrm{r}$ denotes the applicable interest rate). Under positive rates without EL (upper left panel of Figure 5) both banks can expect the same net present value (NPV) of their stream of profits, providing a general 
equilibrium rationale for the existence of both business models at the same time. ${ }^{15}$ In the presence of EL (upper right panel), both bank types earn a positive rate of return for their EL holdings (e.g. DFR) and, again, have equal NPVs, as the costs of holding EL in a positive rate environment are unrelated to banks' funding structure. Note that the insight from the upper right panel of Figure 5, i.e. that EL does not change banks' fundamental business prospects, is also backed by empirical research (see Ennis and Wolman (2015) for the case of the US).

Things change once policy rates are lowered below zero. The wholesale-funded bank is not affected as its liabilities fully reprice. The retail deposit-funded bank, however, is negatively affected as its liabilities cannot reprice fully and the NPV of its profits declines relative to the NPV of the profits of the wholesale-funded bank (lower left panel of Figure 5). ${ }^{16}$ Importantly, this situation is worse when the banking system is forced to hold EL (e.g. due to asset purchases). The NPV of the profits of the retail deposit-funded bank further deteriorates relative to the one of the wholesale-funded bank as it has to hold costly EL (lower right panel of Figure 5).

This classification of effects of NIRP on banks with and without EL also helps understanding the differences in the literature: Papers relying on retail deposit intensity (e.g. Heider et al, 2019; Eggertsson et al., 2017) base their identification on the channel described in the lower left panel of Figure 5. Meanwhile, our approach identifies the transmission channel described in the lower right panel of Figure 5. In this way, we are able to capture the incidence of the direct costs of the NIRP and the scope for portfolio adjustment through EL

\footnotetext{
${ }^{15}$ The NPV is represented by the thickness of the red and black bars next to the balance sheets of both types of banks. NPV is used in this stylised illustration as a summary metric that allows us to compare the dynamic effects of different rate and asset/liability structure constellations.

${ }^{16}$ Molyneux et al. (2019) verify this claim empirically by showing that negative effects of NIRP on profits and margins are stronger for banks that have more interest-oriented business models. Similarly, focusing on German banks, Urbschat (2018) shows that high deposit banks face lower interest income during the NIRP and QE period.
} 
holdings while also capturing the exposure to the indirect effects associated with margin compression through the retail deposit funding intensity.

A more fundamental adjustment option for affected banks would be to change their funding models (i.e. to reduce their reliance on retail deposits). Such decisions, however, are of a more long-term nature and need to be weighed against the fixed costs associated with switching to a new funding model as well as the benefits of the new funding model under positive interest rates. In an environment where negative rates are considered temporary, we would rather expect the retail deposit-funded banks to adjust their EL holdings instead of changing their business models. Urbschat (2018) finds evidence for this claim for German banks where banks on average were not able to substitute deposit funding with wholesale funding. In section 6.3 we present further evidence that banks in our sample do not change their business models.

\section{Empirical results}

\subsection{Bank loans}

We start with the question whether NIRP prompts banks to extend more loans, over and above what would be implied by the standard determinants of loan issuance. In line with the established approach in the literature we use a Difference-in-Differences (DiD) methodology in our estimation. ${ }^{17}$ The DiD methodology assumes that except for the treatment, treated and non-treated entities are affected by economic conditions in the same way. The advantage of this methodology is that it accounts for the potential endogeneity between the economic control variables and the dependent variable, if the underlying assumptions about the treated and non-treated groups are valid.

\footnotetext{
${ }^{17}$ Our results are robust if we split banks into three quantiles based on the size of retail deposits in the year before NIRP and estimate a panel fixed effects model. The results are available from the authors upon request.
} 
As a starting point, we consider the following equation for bank loans $\left(Y_{i t}\right)$ consistent with the literature on NIRP:

$$
Y_{i t}=T_{t}+B_{i}+\beta_{1} A v g_{-} R R_{i} D^{N I R}+\varepsilon_{i t}
$$

where $A v g_{-} R R_{i}$ is the average retail deposit ratio of bank $i$ in the year before NIRP. $D^{N I R}$ is a dummy variable that is equal to 1 for the period after June 2014 when the deposit facility rate moved to negative territory. We include bank fixed effects $\left(B_{i}\right)$ to control for unobservable time-invariant bank-specific factors that affect the decision to extend loans. Moreover, our specifications include time fixed effects $\left(T_{t}\right)$ to control for aggregate shocks. The errors are clustered at the bank level. The estimation sample covers the period from 2010.Q1 to 2017.Q4. To avoid that our results are unduly influenced by outliers, all banklevel flow data are winsorized at the 1 and 99 percent levels.

The interaction term $A v g_{-} R R_{i} D^{N I R}$ captures the treatment intensity of bank $i$ that is associated with its reliance on retail deposits. If banks with a high reliance on retail deposits are indeed more motivated than low deposit banks to turn their EL into loans during the NIRP period, we would expect $\beta_{1}>0$.

Table 1 displays the estimation results. Columns 1-2 show the results for the full sample. The first column refers to the ratio of winsorized non-financial private sector (NFPS) loan flows to total assets as the dependent variable $\left(Y_{i, t}=\right.$ Loan ratio $_{i, t}=\frac{\text { Loans }_{i, t}}{\text { Assets }_{i, t-1}}$, where Loans $_{i, t}$ is the quarterly net flow ${ }^{18}$ in loans to the non-financial private sector (i.e. to households and non-financial corporations) in period $\mathrm{t}$ and Assets $_{i, t-1}$ is the stock of assets at the end of period t-1). The second column shows the results using the log difference of the stock of loans to the non-financial private sector as the dependent variable. We prefer to

\footnotetext{
${ }^{18}$ Net flows are gross new loans minus repayments of previously existing loans.
} 
focus on flow data, which are insulated from reclassifications and other changes in stocks that do not refer to actual transactions. Nevertheless, in order to provide continuity with the literature, we also report the results using stock data. Unlike previous literature (e.g. Heider et al., 2019, Eggertsson et al., 2017), we do not find a negative and significant coefficient. At the same time, we do not find a positive coefficient either. Restricting the sample to "high deposit" banks in columns 3-4 does not change the results. High deposit banks are defined as those banks whose average retail deposit ratios in the year before NIRP were above the median. When we restrict our sample to those banks active in the syndicated loan market, ${ }^{19}$ however, we replicate the negative and significant relationship using stock data (column 6), consistent with Heider et al. (2019). ${ }^{20}$ This finding holds for the high deposit banks active in the syndicated loan market as well (column 8). Nevertheless, these results are fragile and do not carry through when we use flow data (columns 5 and 7).

These results could be a consequence of the exposure to the treatment being relatively heterogeneous within our high deposit group, given that we have a broader cross-section than some of the previous studies in the literature, which either focus on a specific country (e.g. Eggertsson et al., 2017) or a specific credit market segment, such as syndicated loans (e.g. Heider et al., 2019). In view of this and in line with the identification strategy proposed in

\footnotetext{
${ }^{19}$ We identify banks that are active in the syndicated loan market based on the following criteria: Database is Dealogic, the extraction period spans 01/12/2013 to 31/12/2015, and returns all tranches of syndicated loans for which at least one of the participating banks has the role "Lead Manager" or "Co-Manager" or "Bookrunner" and at least one of the participating banks has euro area nationality. This is consistent with Heider et al. (2019) where the set of euro area lead arrangers serves as the basis for identification. Roughly half of the loans in their sample actually have a unique lead arranger and the average number of lead arrangers is 3.6 . We cover 37 of the banks used in Heider et al. (2019) and 3 banks not covered in their sample. Not all banks active in the syndicated loan market are present in our dataset covering banks' individual balance sheet data. Other reasons for the imperfect overlap are (i) we exclude banks from Cyprus and Greece since these banks were affected by domestic and banking crises and (ii) we exclude banks that are particularly affected by the ECB's APP.

${ }^{20}$ While our coefficient estimate is qualitatively comparable to the one in Heider et al., 2019, the magnitudes cannot easily be compared because (i) Heider et al. use the log of syndicated loan volume as the dependent variable while we either use the log difference of the stock of total bank loans or the ratio of the flow of bank loans as a percentage of total loans. (ii) They use monthly data whereas we report our analysis at the quarterly frequency (iii) we use banks to identify syndicated loans while Heider et al. (2019) use loans directly and (iv) our loan data are net loans while Heider et al. use gross loans.
} 
section 4.2 we explicitly consider the role of EL in equation (3) in order to better identify exposure to treatment:

$$
Y_{i t}=T_{t}+B_{i}+\beta_{1} A v g_{-} E L_{i} D^{N I R}+\varepsilon_{i t}
$$

where $A v g_{-} E L_{i}$ is the average EL ratio of bank $i$ in the year before NIRP.

Columns 1-2 of Table 2 show the results from estimating (3) for the full sample.

While the coefficient for the interaction term $A v g_{-} E L_{i} D^{N I R}$ is positive, it is not significant for our benchmark specification using flow data (column 1). Next, we restrict our sample to high deposit banks. Consistent with the transmission mechanism and the identification strategy described in section 4.2, we expect these banks to be more responsive to their EL holdings during NIRP. Indeed, the interaction term is positive and highly significant in the third column, suggesting that higher values of EL are associated with increased lending during NIRP. Based on the results presented in Table 2, the NIRP effect corresponds on average to 15 percent of the quarterly lending by high retail deposit banks. ${ }^{21}$

The fourth column in Table 2 considers log differences of stock NFPS loans as the dependent variable. This is consistent with Eggertsson et al. (2017) who focus at Swedish banks and consider the log difference of loans instead of log levels. This way, the trend component of the stock variable can be eliminated and the dependent variable gets "closer" to the net flow variable that we prefer to use in our benchmark regressions. The coefficient estimate associated with the interactive term is once again positive and highly significant supporting our findings in the third column.

Further support for our identification is provided in columns 5 and 6 where we restrict our sample to low deposit banks, which are defined as those banks whose average retail

\footnotetext{
${ }^{21}$ In order to estimate the economic significance of our results, we calculate the ratio: $\frac{\beta_{1} \times \text { Avg EL Ratio }}{\text { Loan flow }_{i}}$ where Loan flow ${ }_{\mathrm{i}}$ is the sample average value of loan flow ratio of high deposit banks during NIRP, Avg EL Ratio is the sample average value of EL ratio for high deposit banks in the year before NIRP, and $\beta_{1}$ is the coefficient estimate from equation (3).
} 
deposit ratios during the year before NIRP were below the median. Our identification mechanism argues that these banks are less exposed to frictions during NIRP and hence they are less likely to attempt to reduce their EL by extending loans. Indeed, the coefficient associated with the interaction term, $A v g_{-} E L_{i} D^{N I R}$, is insignificant. For the sake of comparison with the literature, the last two columns in Table 2 show the corresponding results for the sample of banks that focus on syndicated loans. We note that the coefficient estimate is insignificant. The fact that the positive and significant NIRP effect that we estimate for the high-deposit banks in the full sample is not also found for banks that are active in the syndicated loans markets is consistent with these banks' use of securities purchases as an alternative adjustment channel (see section 5.2 below) owing to their business model. ${ }^{22}$

For the conclusions stemming from the DiD specification in equation (3) regarding the role of NIRP in influencing lending behaviour to hold, it is necessary to assume that the lending of low EL banks provides an appropriate counterfactual for the lending of high EL banks in the absence of NIRP. We assess the validity of this assumption in several ways. First, we plot the average loans extended by high EL and low EL banks in the high-deposit sample in Figure 6. High EL and low EL banks are defined as banks with average EL ratios above and below the median in the year before NIRP. The upper panel shows the full sample of banks while the lower panel focuses on high deposit banks. For both samples, we note that bank lending moves roughly in parallel across the high EL and low EL two groups since 2008, well before the start of our sample period in 2010 .

Next, we check whether characteristics of high versus low EL banks that are relevant for their lending decisions change significantly between the pre and post-treatment period. If

\footnotetext{
${ }^{22}$ Banks active in the syndicated loan market generally display a lower reliance on deposit funding (Table 8, row 6) compared to the high-deposit group in the full sample (Table 8 , row 8 ). The difference is statistically significant.
} 
this is the case, it could indicate that there are relevant time-varying differences in the two groups which could blur the identification of NIRP. Table A1.2 presents averages of relevant balance sheet features across banks in the top and bottom terciles of average EL holdings. The top panel reports these averages for the pre-NIRP period, while the bottom one refers to the NIRP period. The last column reports the value of the t-statistic for a test of whether the difference in means between the two groups is equal to zero. In the pre-NIRP period, low EL banks have higher levels of retail deposits, they are more liquid, smaller in size, they have larger wholesale funding ratios and higher leverage ratios. As shown in the bottom panel, this pattern of differences is broadly preserved in the NIRP period. The only exception is the leverage ratio (row 3), where the difference between the two groups is no longer significant in the NIRP period. As, however, in the pre-NIRP period the high-EL group had a lower leverage ratio (implying lower capitalisation in the way the ratio is defined), this would have motivated, if anything, lower - not higher - lending by this group.

Finally, a potentially relevant concern is that there may be confounding effects from changes that are not related to NIRP and not properly differenced out by the DiD estimation. If such factors affected banks' lending decisions and impacted treated and non-treated banks in different ways, our identification would be invalid. One such potentially confounding factor is the introduction of the Basel III Liquidity Coverage Ratio (LCR), which came into force in January 2015, albeit with a 4-year phasing-in period. If low EL banks had systematically lower LCR than their high EL peers, they may have restrained their lending in order to improve their liquidity position and comply with the regulatory requirement. In this case the post-treatment difference in lending between high EL and low EL banks would be driven by this regulatory change rather than NIRP. To check the validity of this argument, we calculate a proxy for the liquidity position of banks in our sample including EL, which is reported in row 7 of table A1.2. As shown in the table, the two sets of banks have statistically 
indistinguishable average liquidity positions, as measured by this proxy, both in the pre and in the post-treatment periods. This provides us with comfort that a different intensity of motivations to comply with liquidity regulatory requirements is not confounding our results.

Table A1.3 replicates Table A1.2 for the sample of high deposit banks. Similar to the full sample, high EL banks are bigger in size and have lower leverage ratios for the pre-NIRP sample. Different from the full sample, however, we see that high EL banks have increased levels of retail deposit ratios during the NIRP sample. This is consistent with the role of deposit intensity in higher loan issuance during that period. High EL banks are also more liquid during this time period.

Table A1.4 shows the corresponding table for low deposit banks. For this group, we observe that low EL banks are associated with lower levels of retail deposit ratios, they are smaller in size, more liquid, and rely on more wholesale funding during both periods. In general, the low deposit sample resembles the full sample for high and low EL banks, except for the retail deposit ratios which are higher for the high EL banks. Nevertheless, the overall retail ratios are an order of magnitude smaller for this group, once again highlighting the importance of deposit intensity in loan issuance.

\subsection{Security holdings}

We follow the same logic as in the previous section to identify the effects of NIRP for bank security holdings in the framework of portfolio adjustment. We focus on government bond holdings and distinguish between those issued by domestic governments and those by other euro area sovereign issuers.

We replace the dependent variable used in equation (2) with bond holdings. Tables 3 and 4 show the results for non-domestic and domestic bond holdings respectively. Overall, our findings do not support a significant adjustment of bond holdings during NIRP. This finding is consistent with Ennis and Wolman (2015) who find no evidence of substitution 
between EL and other forms of liquid assets for the US (albeit for a period with positive interest rates). A reason for the missing adjustment into bonds could be that yields of euro area sovereign bonds, particularly higher-rated ones and those with shorter maturities than 10 years, were trading, for much of the NIRP period, close to or even below the DFR, rendering an exchange of EL for sovereign bonds relatively unattractive. For the sample of banks active in the syndicated loan market, however, we do observe a significant increase in their domestic bond holdings. The choice of this particular adjustment channel is likely a reflection of their business model, as these banks, typically investment banks, have larger securities holdings than other banks (Table 8, row 6). and thus are also more likely to resort to purchases of securities as an adjustment strategy rather than loans, not least because they are likely to be better equipped to deal with the assumption of interest rate risk that is associated with making such holdings profitable.

\subsection{Wholesale funding}

Wholesale funding refers to uninsured bank liabilities such as inter-bank loans and debt securities issued that provide additional funding opportunities beyond retail deposits. Wholesale funding, owing to its uninsured nature, tends to be costlier than retail deposits and can, in some cases, be adjusted flexibly. At the same time, in a NIRP environment it is not subject to an effective lower bound and can therefore become relatively less costly than retail deposits. As discussed in Section 3, one potential impact of NIRP could be to motivate banks to use their EL to pay back wholesale funding debt, but we would expect this channel, if anything, to be more muted than the others due to the potential beneficial impact wholesale funding can have on banks' funding cost under NIRP.

Table 5 shows the results from estimating equation (2) for wholesale funding. Opposite to what we would expect ex-ante, we find evidence of a statistically significant (at 
the $90 \%$ level) increase in wholesale funding during NIRP for affected banks. ${ }^{23}$ This finding is not robust, however, when we consider the panel estimation methodology in Appendix 2. Table A2.4 shows that there is not a significant adjustment in wholesale funding associated with higher levels of EL.

\section{Robustness analysis}

In the previous section, we documented that high deposit banks with higher levels of EL holdings extend more loans during NIRP. We check the robustness of this result in several ways.

\subsection{Different Cut-off Points}

First, we consider an alternative cut-off point for various reductions of the DFR in positive territory to determine if the NIRP period is indeed special. Our goal is to understand whether other reductions in the DFR that took place in positive territory trigger reactions similar to the reductions in negative territory. To this end, we construct a dummy variable, $D^{12}$, to capture the 25 basis point easing in July 2012 and the further easings in positive territory that followed. We interact this dummy variable with $A v g_{-} E L_{i}$ and add it to our specification. If the extension of bank loans by high deposit banks with high EL exposure is simply a response to expansionary monetary policy, then we might expect the coefficient associated with $D^{12}$ to be significant as well and perhaps even dominate the coefficient $\beta_{1}$. However, the results shown in the first column of Table 6 illustrate that this is not the case. $A v g_{-} E L_{i} \times D^{N I R}$ is the only significant interaction term, suggesting that it is only during NIRP that the transmission channel that operates through banks' EL holding is operative. The second column considers another robustness check, analysing the impact of progressive steps into negative territory, compared to the period when the DFR was positive.

\footnotetext{
${ }^{23}$ Low deposit banks appear to adjust with greater significance (at the $95 \%$ level) but we cannot ascribe this effect to NIRP in line with the discussion on our identification.
} 
Accordingly, we split the NIRP period into four partially overlapping sub samples: $D^{N I R}$ starts from the first rate cut and covers all successive cuts in negative territory, $D^{D F R 2}$ covers the period after the second rate cut in September 2014, which lowered the deposit facility rate to -0.20 percent, $D^{D F R 3}$ covers the period after the third cut into negative territory in December 2015, and $D^{D F R 4}$ covers the period after March 2016, when the DFR was -0.40 percent.

The first period with a negative DFR ( $\left.D^{D R F 1}\right)$ was relatively short (3 months), left short-term money market rates largely above zero due to a sluggish pass-through, and was generally associated with lower levels of EL. In contrast, the cut in the DFR to -0.30 percent in December $2015\left(D^{D R F 3}\right)$ marks the point when financial markets revised their expectations regarding the future path of short rates because what was previously thought to be the lower bound (essentially because of previous communication by the ECB on the topic) had to be revised downwards. ${ }^{24}$ Thus, we would expect our results to be driven by the later NIRP subperiods rather than the earlier sub-periods. In addition to determining which phase of NIRP was more influential, this robustness check also allows us to see whether the data contains any hint regarding a potential reversal rate. For example, while we might find an overall effect where banks expand their loan supply in the face of NIRP, this effect might get smaller and ultimately reverse, depending on the degree of negativity of the DFR.

The third column considers another robustness check for bank loans by controlling for the APP period explicitly. The APP variable is constructed based on Blattner and Joyce (2016), which yields the probability of the ECB implementing APP based on survey evidence. The variable starts with a positive probability in September 2014 and increases gradually to 1 by January 2015 .

\footnotetext{
${ }^{24}$ Grisse et al. (2017) note that if rate cuts below zero shifts the believed lower bound, this affects the long term rates and strengthens the transmission mechanism. Wu and Xia (2017) support this argument. Lemke and Vladu (2017) show evidence of a decline in the lower bound during NIRP.
} 
Looking at the first row and the second column of Table 6, we observe that there is no gradual empowerment of the NIRP process but the rate cuts as a whole are significant. Most importantly, we find no indication of the banking system approaching a "reversal rate" which would have manifested itself in negative responses (coefficients) at the later stages of NIRP. The third column indicates that the aggregate impact of EL is still significant for the high deposit banks even after we control for APP according to Blattner and Joyce (2016).

The last column in Table 6 considers yet another robustness check and includes country fixed effects instead of cross section fixed effects. We observe that our benchmark specification is robust to this test as well, suggesting that our findings are not driven by country-specific differences that may have affected bank lending behaviour.

\subsection{Panel Regressions}

As an additional robustness check, we address some of the weaknesses of the DiD methodology and consider panel data regressions with control variables as an alternative. The main advantage of $\mathrm{DiD}$ is its potential to circumvent endogeneity problems. One limitation in this framework, however, is the fact that banks with different business models may not necessarily provide a plausible counterfactual for each other. In fact, banks with high deposit reliance may be more likely to resort to additional lending than banks that rely more on market funding. We partly address this issue by focusing on identification within a business model, hence relying on a more narrow identification. Specifically, instead of comparing the behaviour of high deposit and low deposit banks in the full sample of banks, we focus on the sample of high deposit banks. Within that sample, we compare the behaviour of high EL and low EL banks. In line with the argument outlined in figure 5, we argue that the lending behaviour of these two groups would be the same in the absence of NIRP. That is, we do not expect to observe any difference in the behaviour of high deposit and high EL banks versus high deposit and low EL banks in a positive interest rate environment. Nevertheless, to the 
extent that high EL and low EL banks face different demand conditions, these differences would not be cancelled out with the DiD methodology and we cannot attribute our findings entirely to changes in loan supply. In order to address this potential weakness, we use panel regressions where we can explicitly control for demand conditions using survey data. Moreover, in the panel setup we can use a time-varying exposure to treatment by incorporating bank fixed effects and allow our EL variable to change over time.

In this panel setup we can also control for loan demand (at the country level), using survey data from the ECB's bank lending survey, where banks report the loan demand conditions they are facing. Our results, shown in Appendix 2 (Table A2-1a), are robust to this change in specification as well, which suggests that high deposit banks with high EL ratios are indeed associated with more loan issuance during NIRP. No similar adjustment is observed for holdings of securities or wholesale funding. While controlling for country-level demand goes some way towards assuaging concerns about differences in demand conditions, the possibility of bank-specific differences in demand within countries remains. While our dataset, which is at the bank level, does not allow us to fully address this, it is comforting to note that in our baseline specification we can replicate Heider et al.(2019), who focus on more granular data on the market for syndicated loans, which allows them to control for demand.

\subsection{Investigation of Bank business models}

Our results so far suggest that a key result in the literature regarding the negative and significant impact of NIRP appears limited to banks active in the syndicated loan market, suggesting that bank business models play a role for the impact of NIRP on banks. As a final robustness check, we thus further explore the relationship of bank lending and NIRP across business models. We categorize banks into different business models based on clustering 
techniques. We group each bank in our sample into a category reflecting its business model, using standard hierarchical clustering methods (Ayadi et al., 2011).

For the cluster analysis, we use balance sheet data as of the end of 2007, to avoid endogeneity, assuming that bank balance sheets exogenously reflect strategic choices made by management with respect to activities and funding. In a first step, we determine instruments to identify banks in similar groups. These instruments are criteria to determine similarities or differences. In line with the literature, we use loan to asset, security to asset, wholesale funding to asset, derivative to asset and retail deposit to asset ratios to categorise banks into different business models. Next, we apply an algorithm to formally measure the similarities and differences between various business models. In line with Ayadi et al. (2011) we use Ward's (1963) methodology and form partitions in a hierarchical manner.

The algorithm first assigns each bank in a different cluster. It then merges clusters by minimizing the within cluster sum of squared deviations from the cluster mean for a given number of clusters. Statistical tests suggest that five different business models exist in our data. A variety of robustness checks, using alternative clustering methods (Gaussian mixture models, k-means, harmonic k-means, see Hamerly and Elkan (2002) for a discussion on the potential alternatives and their advantages and disadvantages) confirm this overall number. Using dynamic clustering methods (dynamic k-means) and allowing for banks switching business models, we establish, in line with the findings of Lucas et al. (2019), that banks in our sample are unlikely to change their business model, at least during the years covered by our sample. Finally, we cross-check the results of our statistical exercise with bank business model classifications available from other sources: supervisory data, rating agencies, commercial providers of bank balance sheet data and banks' annual reports.

Table 7 illustrates the business models that are exploited in our empirical identification. By controlling for bank business models we are able to capture two aspects that are key for 
banks' reaction to negative rates: the difference in their costs of holding EL and in their ability to adjust to these costs. Both dimensions should be reflected in a bank's business model.

Looking at the balance sheet decompositions of different business models, the focused retail group holds the largest percentage of retail deposits, followed by the diversified retail group (Table 8). Consistent with our baseline results, we expect these banks to be more aggressive in adjusting their portfolios to reduce their EL during NIRP compared to other business models. In terms of EL ratios, investment banks are followed by diversified retail and focused retail groups.

Table 9 illustrates the estimation results using business models in our baseline DiD framework. The results are consistent with Table 2 in that banks with higher retail ratios, in particular the focused retail group, extend significantly more loans associated with higher levels of EL during NIRP. ${ }^{25}$

\section{Conclusions}

The existing theoretical and empirical literature on banks' role in the monetary policy transmission mechanism is to some extent inconclusive on bank reactions to changes in policy rates when these changes take place in negative territory. Using confidential banklevel data for the euro area which cover a representative share of total loans, we approach this question empirically, using a novel identification approach. We jointly consider banks’ exposure to the charge on EL and their reliance on retail deposit funding, as an essential identification mechanism for the impact of NIRP on banks. We find evidence that banks indeed operate differently under negative rates. Banks that are highly exposed to NIRP (i.e. funded by large amounts of retail deposits and holders of relatively high levels of EL) extend

\footnotetext{
${ }^{25}$ Banks who are identified to lend more during NIRP using our methodology are banks with a significant franchise in domestic retail loan markets, like (large) savings banks in Germany (Sparkassen and Volksbanken) and (large) regional savings banks in Spain (Cajas).
} 
significantly more loans to households and firms during the NIRP compared to the pre-NIRP period. These results suggest the presence of a strong complementarity between NIRP and other easing measures injecting central bank liquidity into the banking system, e.g. asset purchase programmes: EL injected by the central bank activates expansionary effects of NIRP over and above what could be expected from a standard rate cut. The charge on EL seems to encourage banks to take action to avoid it, thereby catalysing more active portfolio rebalancing. Our results are consistent with results in the literature on the impact of NIRP in that we do find evidence of higher risk taking by banks, as risk-free central bank deposits (i.e. excess liquidity) is converted into loans. However, in contrast to some of these contributions, we find that high retail deposit banks increase their lending during NIRP. We document that our different result is driven by the sample of loans considered, while we confirm the contractionary impact of NIRP on lending by banks active in the syndicated loan market, as shown by Heider et al. (2019). 


\section{Figures}

Figure 1: Key policy-controlled interest rates and interbank overnight rates

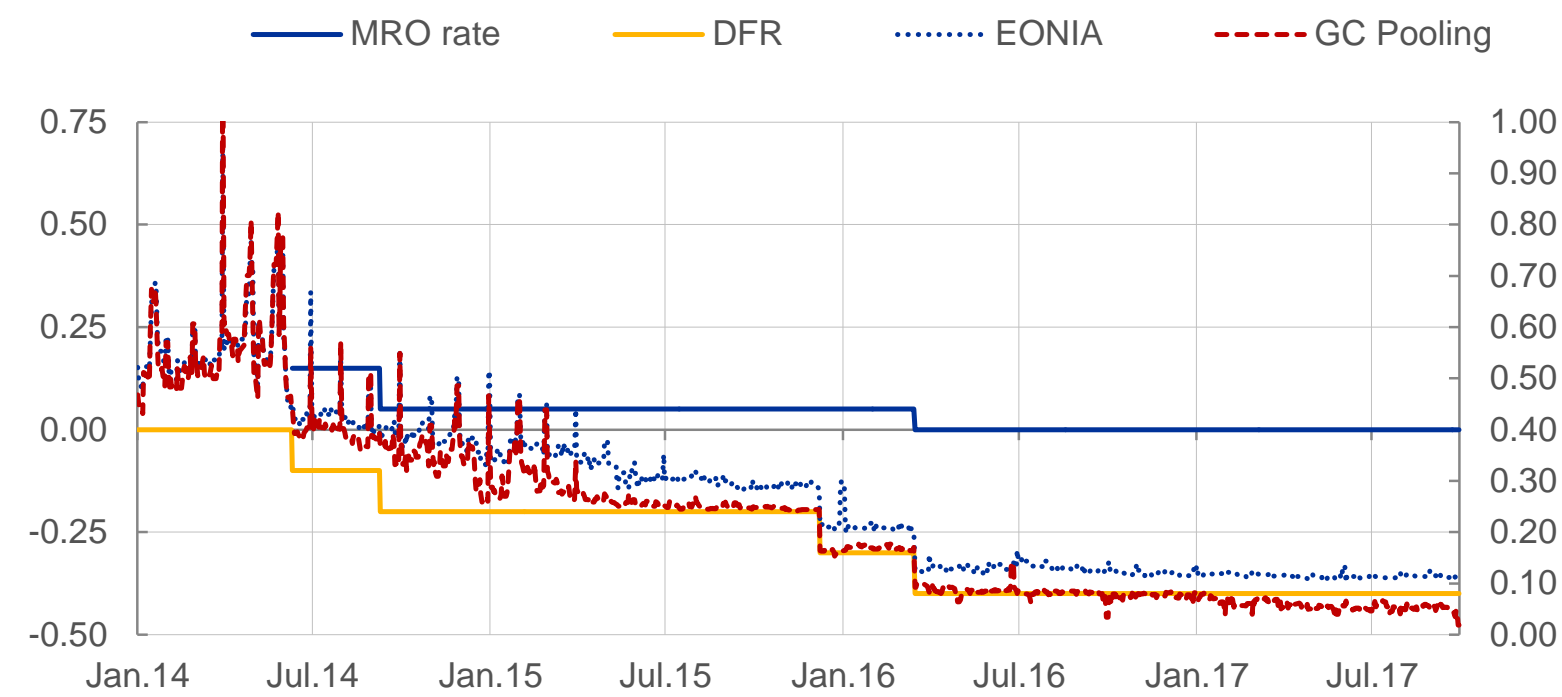

Sources: ECB, and Eurex 
Figure 2: Distribution of the remuneration of household and NFC deposits across banks in the euro area - updated 2017Q3

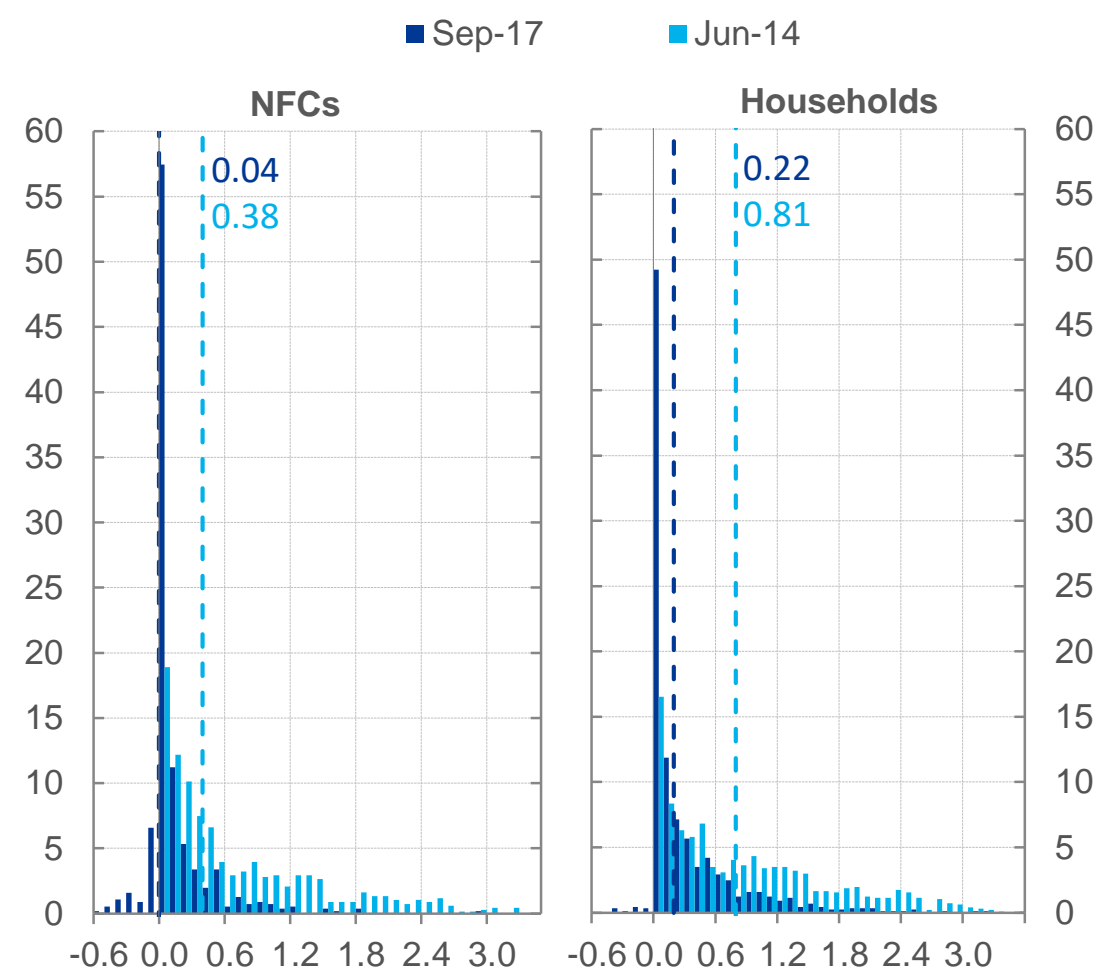

Source: $\mathrm{ECB}$

Notes: Dashed lines represent the mean of the respective distribution 
Figure 3: Possible adjustment channels for banks to reduce their excess liquidity holdings

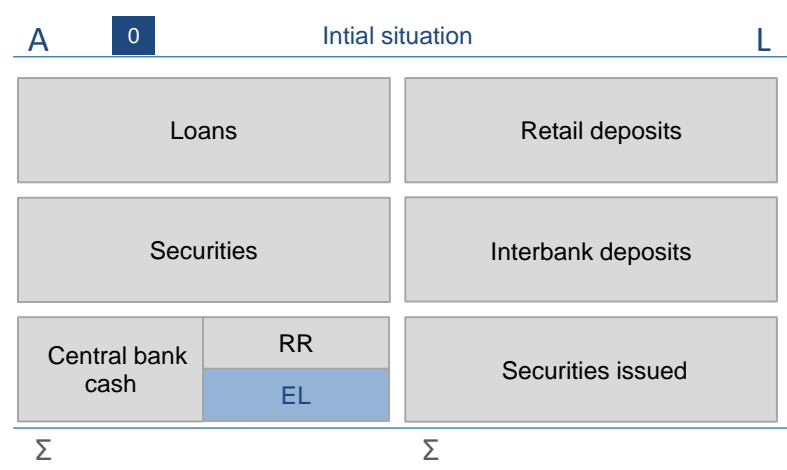

A
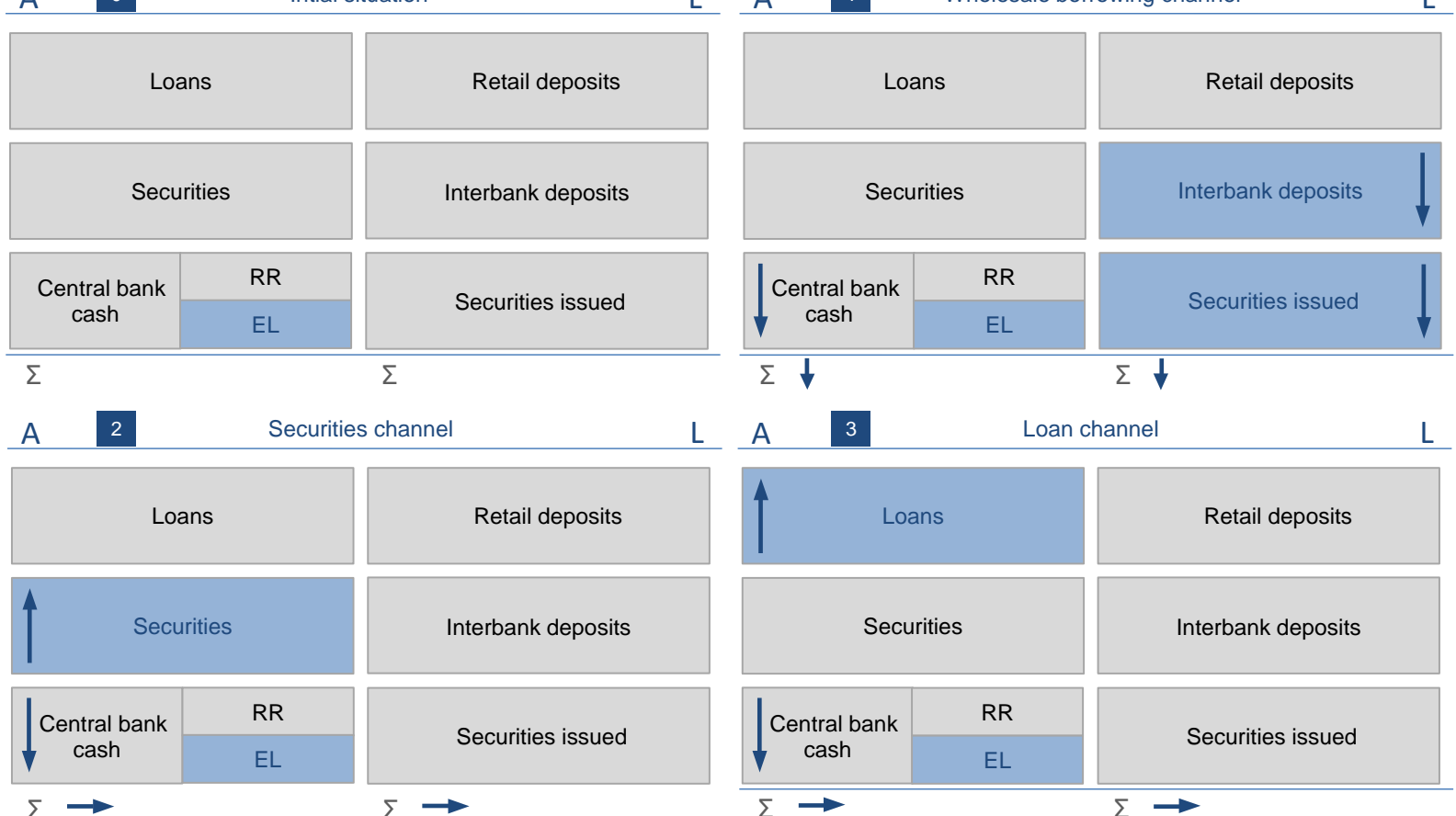

L $A$

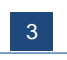

Loan channel

\begin{tabular}{|c|c|c|}
\hline \multicolumn{2}{|c|}{ Loans } & Retail deposits \\
\hline \multicolumn{2}{|c|}{ Securities } & Interbank deposits \\
\hline \multirow{2}{*}{$\begin{array}{l}\text { Central bank } \\
\text { cash }\end{array}$} & $\mathrm{RR}$ & \multirow{2}{*}{ Securities issued } \\
\hline & EL & \\
\hline
\end{tabular}

Source: Authors

Notes: "RR" stands for required reserves 
Figure 4: Scatterplot of EL Rankings Before and After NIRP for High Deposit Banks

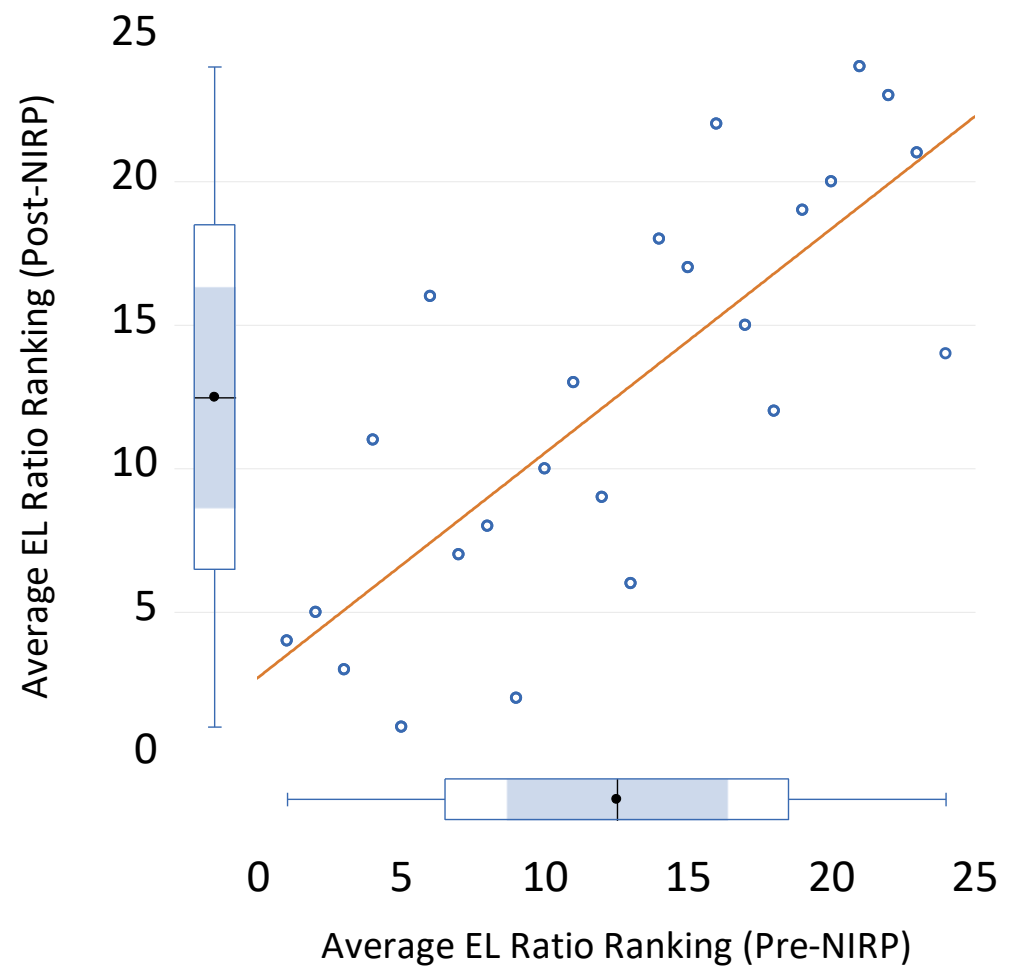

Sources: ECB, authors' calculations.

Notes: The scatterplot shows the rankings of high deposit banks based on their average EL holdings before and after NIRP. High deposit banks are defined as those in the top tercile based on their retail deposit ratios in the year before NIRP. 
Figure 5: Comparison of two bank funding types under different interest rate environments
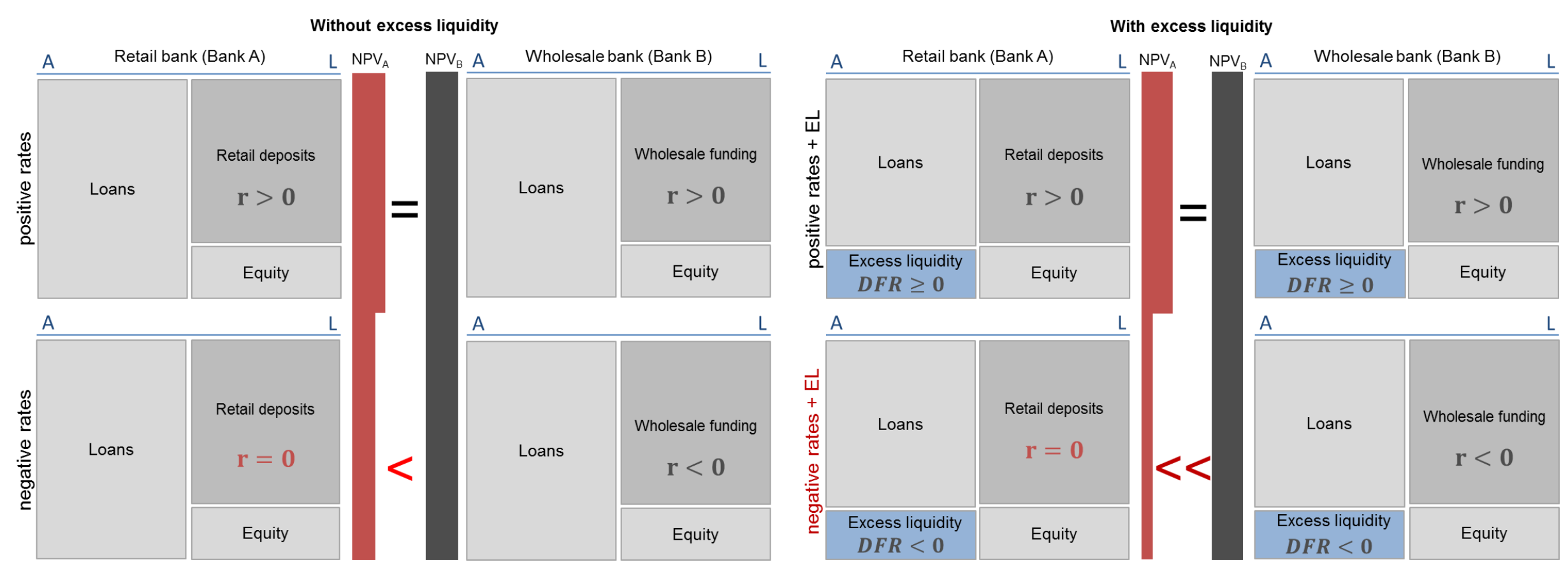

Source: Authors. 
Figure 6: Evolution of Bank Loans by High EL and Low EL Banks

\section{Full Sample}

- Average loans flow ratio of Low EL banks

-Average loans flow ratio of High EL banks

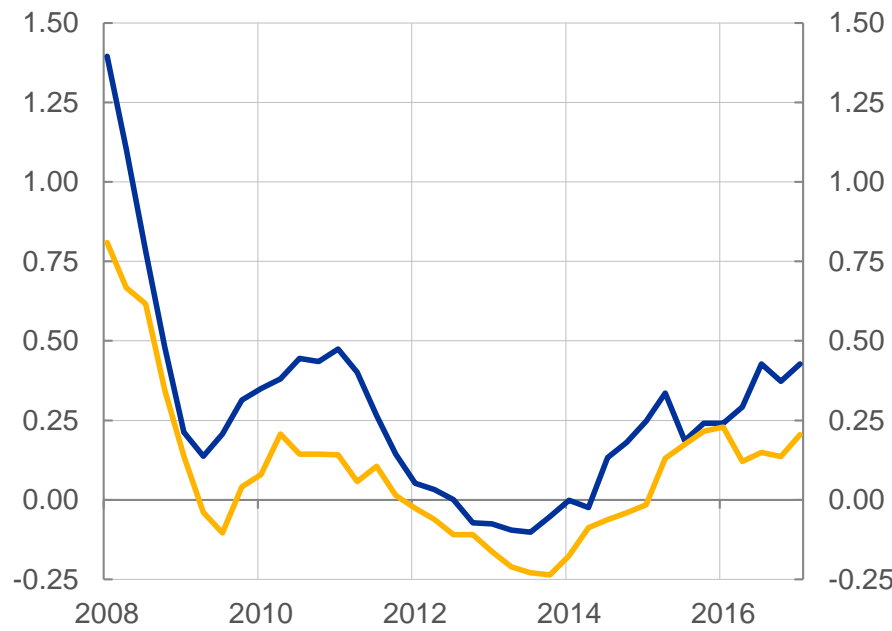

High Deposit Banks

-Average loans flow ratio of Low EL banks

Average loans flow ratio of High EL banks

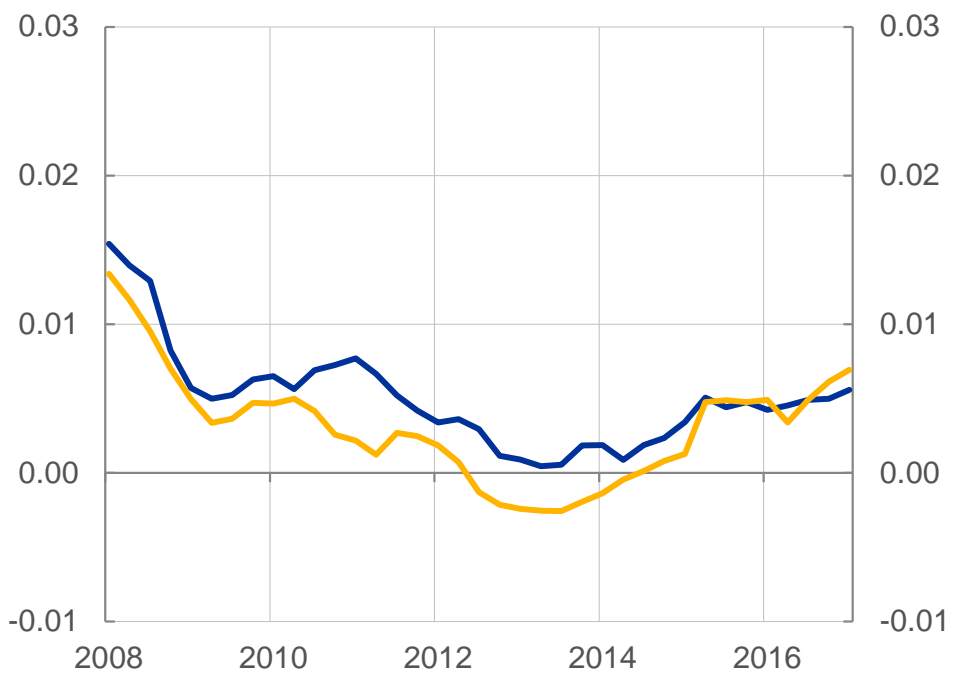

Sources: ECB, authors' calculations.

Notes: High EL and Low EL banks are defined as those banks with average EL ratios above and below the median in the year before NIRP, respectively. 
Table 1: Role of Deposits in Lending Behavior

\begin{tabular}{|c|c|c|c|c|c|c|c|c|c|}
\hline & \multirow{2}{*}{\multicolumn{2}{|c|}{$\begin{array}{c}\text { (1) } \\
\text { Full Sample }\end{array}$}} & \multirow{2}{*}{\multicolumn{2}{|c|}{$\begin{array}{c}(3) \\
\text { High-Deposit Sample }\end{array}$}} & \multirow{2}{*}{\multicolumn{2}{|c|}{$\begin{array}{l}\text { Syndica } \\
\text { Sample }\end{array}$}} & \multirow{2}{*}{\multicolumn{2}{|c|}{$\begin{array}{l}\text { (7) } \\
\text { High-Deposit }+ \\
\text { Syndicated Loan Sample }\end{array}$}} \\
\hline & & & & & & & & & \\
\hline & & $\begin{array}{l}\text { Ratio of } \\
\text { Winsorized } \\
\text { Loan Flow }\end{array}$ & $\Delta \operatorname{Ln}($ Loans $)$ & $\begin{array}{l}\text { Ratio of } \\
\text { Winsorized } \\
\text { Loan Flow }\end{array}$ & $\Delta \operatorname{Ln}($ Loans $)$ & $\begin{array}{l}\text { Ratio of } \\
\text { Winsorized } \\
\text { Loan Flow }\end{array}$ & $\Delta \operatorname{Ln}$ (Loans) & $\begin{array}{l}\text { Ratio of } \\
\text { Winsorized } \\
\text { Loan Flow }\end{array}$ & $\Delta \operatorname{Ln}($ Loans $)$ \\
\hline 1. & $A v g_{-} R R_{i} \times D^{N I R}$ & $\begin{array}{l}0.00 \\
0.00\end{array}$ & $\begin{array}{l}0.02 \\
0.02\end{array}$ & $\begin{array}{l}0.00 \\
0.00\end{array}$ & $\begin{array}{l}0.07 \\
0.04\end{array}$ & $\begin{array}{l}0.00 \\
0.00\end{array}$ & $\begin{array}{l}-0.05^{* *} \\
0.02\end{array}$ & $\begin{array}{l}0.00 \\
0.01\end{array}$ & $\begin{array}{l}-0.05^{*} \\
0.03\end{array}$ \\
\hline 2. & $\begin{array}{l}\text { Cross section fixed } \\
\text { effects }\end{array}$ & Yes & Yes & Yes & Yes & Yes & Yes & Yes & Yes \\
\hline 3. & Time fixed effects & Yes & Yes & Yes & Yes & Yes & Yes & Yes & Yes \\
\hline 4. & Observations & 6383 & 6255 & 3339 & 3346 & 1881 & 1862 & 894 & 895 \\
\hline 5. & R-Squared & 0.13 & 0.06 & 0.18 & 0.05 & 0.37 & 0.10 & 0.44 & 0.06 \\
\hline 6. & Number of IDs & 214 & 211 & 111 & 111 & 61 & 61 & 29 & 29 \\
\hline
\end{tabular}

Robust standard errors underneath coefficient estimates.

$* * *_{\mathrm{p}}<0.01, * *_{\mathrm{p}}<0.05, * \mathrm{p}<0.1$ 
Table 2: Role of EL and Deposits in Lending Behavior

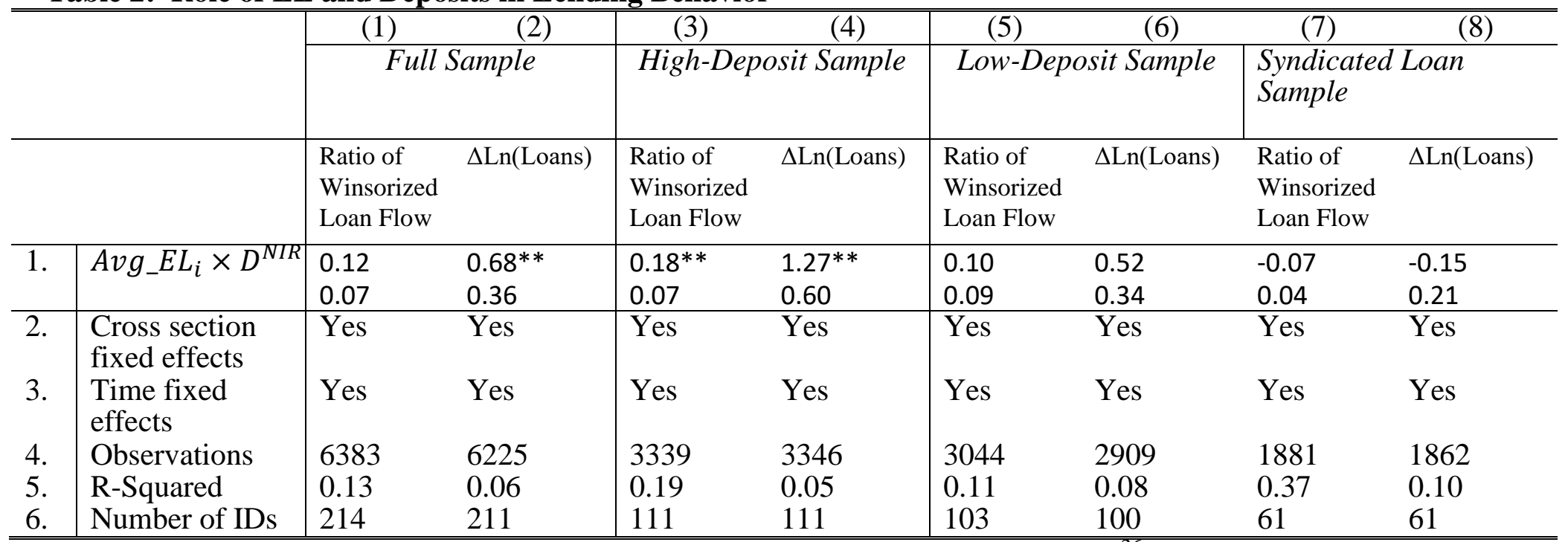

Robust standard errors underneath coefficient estimates. $* * * \mathrm{p}<0.01, * * \mathrm{p}<0.05, * \mathrm{p}<0.1^{26}$

${ }^{26}$ To address issues related to serial correlation, we ran the analysis on collapsed pre and post NIRP periods as sugested in Bertrand et al., 2004. Specifically, we averaged the data before and after NIRP to ignore the time series information and ran a DiD estimation on this averaged sample in a panel of length 2 . The results from this exercise are shown below. The results indicate that extension of loans is significant for the full sample and marginally significant for the high deposit sample but it is not significant for the low deposit sample.

Robustness Check using Bertrand (2004) methodology

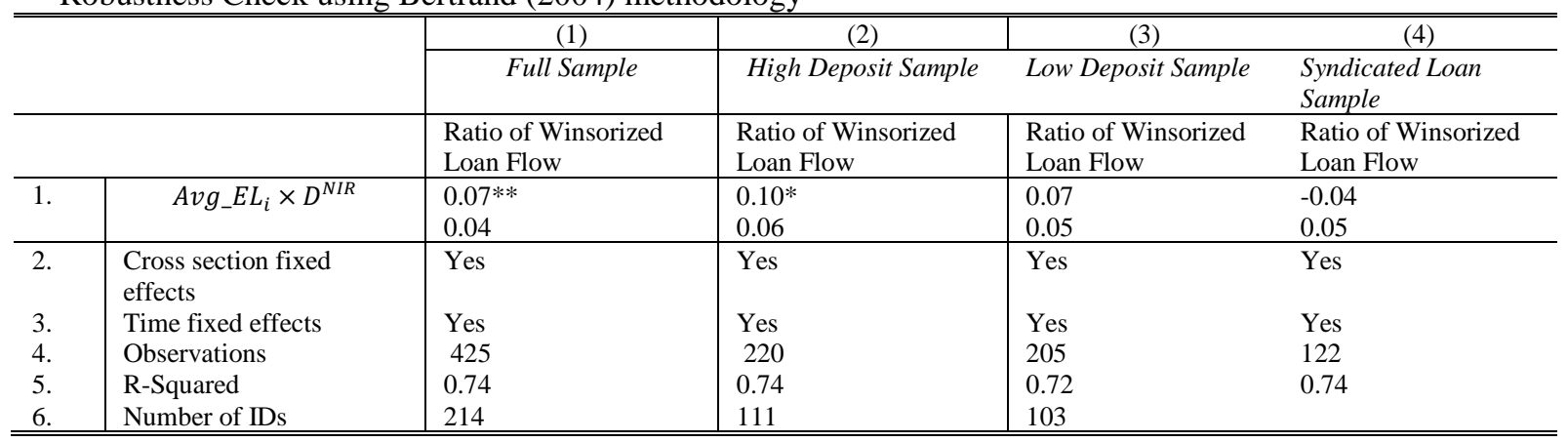


Table 3: Role of EL and Deposits in Non-domestic Bond Purchases

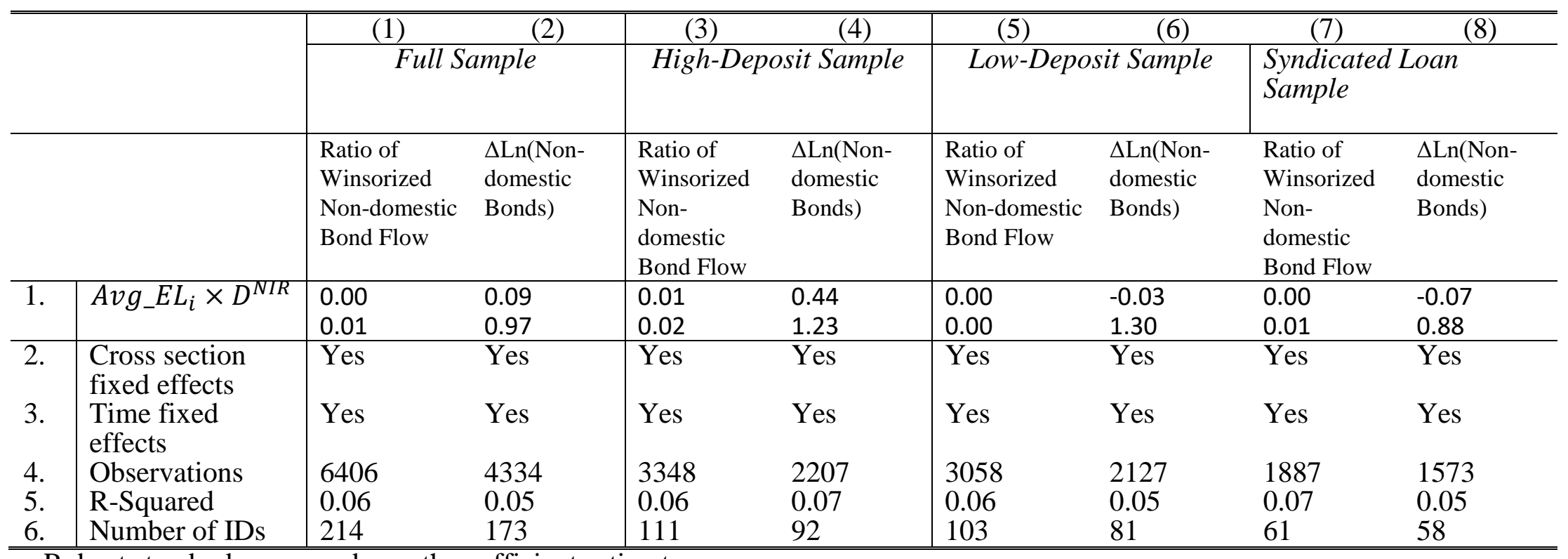

Robust standard errors underneath coefficient estimates.

$* * * \mathrm{p}<0.01, * * \mathrm{p}<0.05, * \mathrm{p}<0.1$ 
Table 4: Role of EL and Deposits in Domestic Bond Purchases

\begin{tabular}{|c|c|c|c|c|c|c|c|c|c|}
\hline & \multicolumn{2}{|c|}{$\begin{array}{ll}(1) & (2) \\
\end{array}$} & \multirow{2}{*}{\multicolumn{2}{|c|}{$\begin{array}{cc}(3) & (4) \\
\text { High-Deposit Banks }\end{array}$}} & \multirow{2}{*}{\multicolumn{2}{|c|}{$\begin{array}{cc}(5) & (6) \\
\text { Low-Deposit Banks }\end{array}$}} & \multicolumn{2}{|c|}{$(7) \quad(8)$} \\
\hline & & \multicolumn{2}{|c|}{ Full Sample } & & & & & $\begin{array}{l}\text { Syndicated } \\
\text { Sample }\end{array}$ & Loan \\
\hline & & $\begin{array}{l}\text { Ratio of } \\
\text { Winsorized } \\
\text { Domestic } \\
\text { Bond Flow }\end{array}$ & $\begin{array}{l}\Delta \mathrm{Ln}(\text { Domest } \\
\text { ic Bonds) }\end{array}$ & $\begin{array}{l}\text { Ratio of } \\
\text { Winsorized } \\
\text { Domestic } \\
\text { Bond Flow }\end{array}$ & $\begin{array}{l}\Delta \operatorname{Ln}(\text { Domest } \\
\text { ic Bonds) }\end{array}$ & $\begin{array}{l}\text { Ratio of } \\
\text { Winsorized } \\
\text { Domestic } \\
\text { Bond Flow }\end{array}$ & $\begin{array}{l}\Delta \operatorname{Ln} \text { (Domest } \\
\text { ic Bonds) }\end{array}$ & $\begin{array}{l}\text { Ratio of } \\
\text { Winsorized } \\
\text { Domestic } \\
\text { Bond Flow } \\
\end{array}$ & $\begin{array}{l}\Delta \operatorname{Ln} \text { (Domest } \\
\text { ic Bonds) }\end{array}$ \\
\hline 1. & $A v g_{-} E L_{i} \times D^{N I R}$ & $\begin{array}{l}-0.02 \\
0.04 \\
\end{array}$ & $\begin{array}{l}-1.76 \\
1.84\end{array}$ & $\begin{array}{l}-0.11 \\
0.14\end{array}$ & $\begin{array}{l}-3.12 \\
3.44 \\
\end{array}$ & $\begin{array}{l}0.00 \\
0.01\end{array}$ & $\begin{array}{l}-0.42 \\
0.96\end{array}$ & $\begin{array}{l}0.07^{* *} \\
0.03\end{array}$ & $\begin{array}{l}1.34^{* *} \\
0.42\end{array}$ \\
\hline 2. & $\begin{array}{l}\text { Cross section } \\
\text { fixed effects }\end{array}$ & Yes & Yes & Yes & Yes & Yes & Yes & Yes & Yes \\
\hline 3. & $\begin{array}{l}\text { Time fixed } \\
\text { effects }\end{array}$ & Yes & Yes & Yes & Yes & Yes & Yes & Yes & Yes \\
\hline 4. & Observations & 6406 & 5581 & 3348 & 3096 & 3058 & 2485 & 1887 & 1805 \\
\hline 5. & R-Squared & 0.05 & 0.06 & 0.05 & 0.06 & 0.06 & 0.08 & 0.07 & 0.05 \\
\hline 6. & Number of IDs & 214 & 198 & 111 & 107 & 103 & 81 & 61 & 60 \\
\hline
\end{tabular}

Robust standard errors underneath coefficient estimates.

$* * * \mathrm{p}<0.01, * * \mathrm{p}<0.05, * \mathrm{p}<0.1$ 
Table 5: Role of EL and Deposits in Wholesale Funding

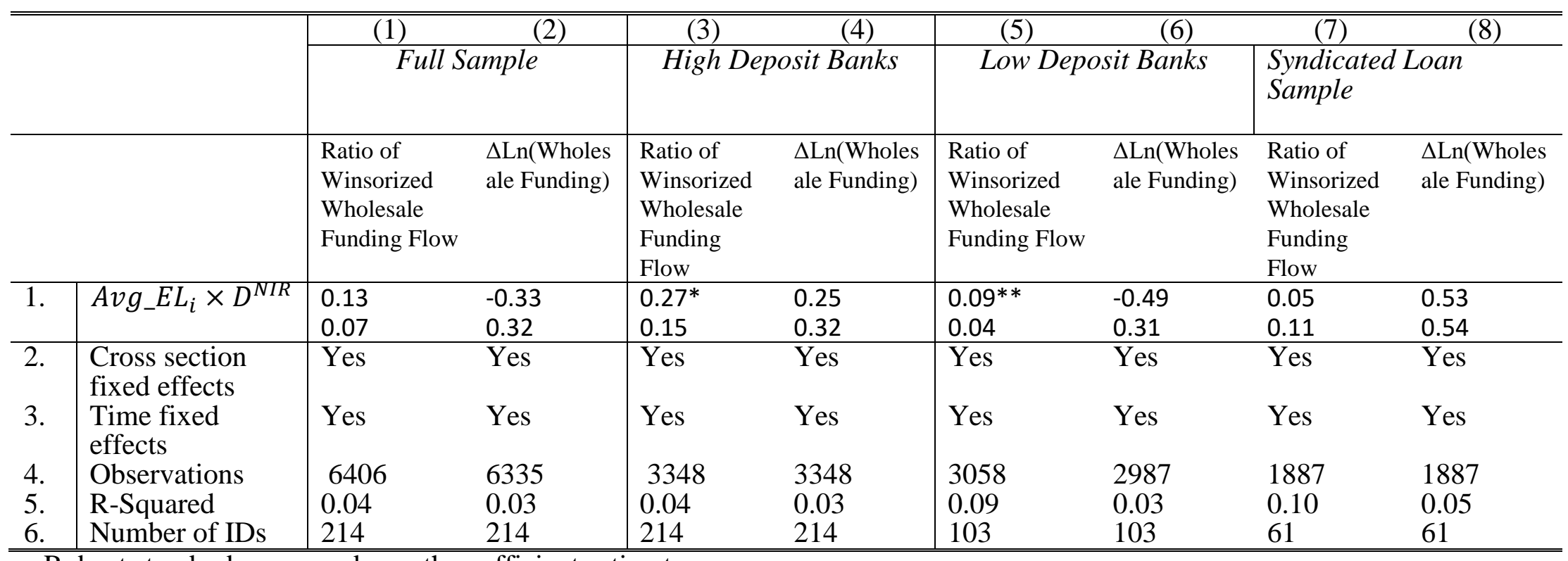

Robust standard errors underneath coefficient estimates.

$* * * \mathrm{p}<0.01, * * \mathrm{p}<0.05, * \mathrm{p}<0.1$ 
Table 6: Robustness tests for Bank Lending

\begin{tabular}{|c|c|c|c|c|c|}
\hline & (1) & (2) & (3) & (4) \\
\hline & & \multicolumn{4}{|c|}{ High Deposit Banks } \\
\hline & & Ratio of & Ratio of & Ratio of & Ratio of \\
\hline & & Winsorized & Winsorized & Winsorized & Winsorized \\
\hline & & Loan Flow & Loan Flow & Loan Flow & Loan Flow \\
\hline \multirow[t]{2}{*}{1.} & $A v g_{-} E L_{i} \times D^{N I R}$ & $0.22^{*}$ & $0.19 * *$ & $0.23^{* *}$ & $0.13^{* *}$ \\
\hline & & 0.13 & 0.08 & 0.11 & 0.06 \\
\hline \multirow[t]{2}{*}{2.} & $A v g_{-} E L_{i} \times D^{12}$ & -0.09 & -- & -- & -- \\
\hline & & 0.14 & -- & -- & -- \\
\hline \multirow[t]{2}{*}{3.} & $A v g_{-} E L_{i} \times D F R^{2}$ & -- & 0.02 & -- & -- \\
\hline & & -- & 0.19 & -- & -- \\
\hline \multirow[t]{2}{*}{4.} & $A v g_{-} E L_{i} \times D F R^{3}$ & -- & -0.16 & -- & -- \\
\hline & & -- & 0.19 & -- & -- \\
\hline \multirow[t]{2}{*}{5.} & $A v g_{-} E L_{i} \times D F R^{4}$ & -- & 0.10 & -- & -- \\
\hline & & -- & 0.08 & -- & -- \\
\hline \multirow[t]{2}{*}{6.} & $A v g_{-} E L_{i} \times D^{A P P}$ & -- & -- & -0.33 & -- \\
\hline & & -- & -- & 0.35 & -- \\
\hline 7. & $\begin{array}{l}\text { Cross section fixed } \\
\text { effects }\end{array}$ & Yes & Yes & Yes & No \\
\hline 8. & Time fixed effects & Yes & Yes & Yes & Yes \\
\hline 9. & Country fixed effects & No & No & No & Yes \\
\hline 10. & Observations & 3339 & 3339 & 3339 & 3339 \\
\hline 11. & R-Squared & 0.19 & 0.19 & 0.19 & 0.11 \\
\hline 12. & Number of IDs & 111 & 111 & 111 & 111 \\
\hline
\end{tabular}

Robust standard errors underneath coefficient estimates.

$* * * \mathrm{p}<0.01, * * \mathrm{p}<0.05, * \mathrm{p}<0.1$ 


\section{Table 7: Bank Business Models}

Business Model

Focused Retail

Diversified Retail

Debt Funded Retail

Investment

Wholesale

\section{Description}

Most active in traditional deposit loan intermediation

Deposit funded, moderate loan origination but also engaged in other activities

Debt based market funding with moderate loan origination but also engaged in other activities, principally investment.

Mixed funding, high investment and trading activities.

High bank lending supported by debt funding.

Table 8: Median Shares of Selected Balance Sheet items by Business Model

\begin{tabular}{|l|c|c|c|c|c|c|}
\hline \multirow{2}{*}{ Business Model } & \multicolumn{3}{|c|}{ Assets } & \multicolumn{3}{c|}{ Liabilities } \\
\cline { 2 - 7 } & $\begin{array}{l}\text { Loans to } \\
\text { NFPS }\end{array}$ & $\begin{array}{l}\text { Government } \\
\text { bonds }\end{array}$ & Excess liquidity & $\begin{array}{l}\text { Retail } \\
\text { deposits }\end{array}$ & $\begin{array}{l}\text { Interbank } \\
\text { deposits }\end{array}$ & $\begin{array}{l}\text { Securities } \\
\text { issued }\end{array}$ \\
\hline 1. Focused retail & $61.06 \%$ & $4.80 \%$ & $0.10 \%$ & $43.46 \%$ & $11.20 \%$ & $3.51 \%$ \\
\hline 2. Diversified retail & $37.25 \%$ & $9.75 \%$ & $0.35 \%$ & $38.81 \%$ & $10.25 \%$ & $7.17 \%$ \\
\hline 3. Debt funded retail & $34.25 \%$ & $7.22 \%$ & $0.03 \%$ & $3.99 \%$ & $21.41 \%$ & $20.81 \%$ \\
\hline 4. Investment & $19.41 \%$ & $2.50 \%$ & $2.92 \%$ & $11.50 \%$ & $20.20 \%$ & $11.30 \%$ \\
\hline 5. Wholesale & $6.64 \%$ & $5.12 \%$ & $0.31 \%$ & $0.05 \%$ & $16.91 \%$ & $16.38 \%$ \\
\hline Memorandum items & \multicolumn{5}{|c|}{} \\
\hline $\begin{array}{l}\text { 6. Banks active in syndicated } \\
\text { loan market }\end{array}$ & $38.40 \%$ & $7.72 \%$ & $0.05 \%$ & $25.64 \%$ & $12.42 \%$ & $11.85 \%$ \\
\hline 7. Low deposit banks & $28.52 \%$ & $6.75 \%$ & $0.14 \%$ & $1.82 \%$ & $18.16 \%$ & $17.40 \%$ \\
\hline 8. High deposit banks & $56.80 \%$ & $6.42 \%$ & $0.05 \%$ & $48.25 \%$ & $9.63 \%$ & $3.09 \%$ \\
\hline
\end{tabular}

Notes: Median values are calculated over the NIRP. High deposit banks are defined as those banks whose average retail deposit ratios in the year before NIRP were above the median. 
Table 9: Role of EL and Business Models in Lending Behavior

\begin{tabular}{|c|c|c|c|c|c|c|c|c|c|c|c|}
\hline & \multirow{2}{*}{\multicolumn{2}{|c|}{$\begin{array}{cc}(1) & (2) \\
\text { Debt Retail }\end{array}$}} & \multirow{2}{*}{\multicolumn{2}{|c|}{$\begin{array}{ll}\text { (3) } & \text { (4) } \\
\text { Diversified Retail }\end{array}$}} & \multirow{2}{*}{\multicolumn{2}{|c|}{$\begin{array}{lr}(5) & (6) \\
\text { Focused Retail }\end{array}$}} & \multirow{2}{*}{\multicolumn{2}{|c|}{$\begin{array}{l}\text { (7) } \\
\text { Investment }\end{array}$}} & \multicolumn{2}{|c|}{$\begin{array}{ll}(9) & (10)\end{array}$} \\
\hline & & & & & & & & & & Whe & lesale \\
\hline & & $\begin{array}{l}\text { Ratio of } \\
\text { Winsorizec } \\
\text { Loan Flow }\end{array}$ & $\Delta \operatorname{Ln}($ Loans $)$ & $\begin{array}{l}\text { Ratio of } \\
\text { Winsorize } \\
\text { Loan Flow }\end{array}$ & $\Delta \operatorname{Ln}($ Loans $)$ & $\begin{array}{l}\text { Ratio of } \\
\text { Winsorized } \\
\text { Loan Flow }\end{array}$ & $\Delta \operatorname{Ln}($ Loans) & $\begin{array}{l}\text { Ratio of } \\
\text { Winsorized } \\
\text { Loan Flow }\end{array}$ & $\Delta \operatorname{Ln}($ Loans $)$ & $\begin{array}{l}\text { Ratio of } \\
\text { Winsorized } \\
\text { Loan Flow }\end{array}$ & $\Delta \operatorname{Ln}($ Loans $)$ \\
\hline 1. & $A v g_{-} E L_{i} \times D^{N I R}$ & $\begin{array}{l}-0.04 \\
0.05\end{array}$ & $\begin{array}{l}0.15 \\
0.39\end{array}$ & $\begin{array}{l}-0.01 \\
0.13\end{array}$ & $\begin{array}{l}1.27 \\
1.62\end{array}$ & $\begin{array}{l}0.08^{* *} \\
0.03\end{array}$ & $\begin{array}{l}0.27^{* *} \\
0.10\end{array}$ & $\begin{array}{l}-0.03 \\
0.09\end{array}$ & $\begin{array}{l}-0.05 \\
0.79\end{array}$ & $\begin{array}{l}1.38 \\
0.29\end{array}$ & $\begin{array}{l}1.63 \\
1.15\end{array}$ \\
\hline 2. & $\begin{array}{l}\text { Cross section } \\
\text { fixed effects }\end{array}$ & Yes & Yes & Yes & Yes & Yes & Yes & Yes & Yes & Yes & Yes \\
\hline 3. & $\begin{array}{l}\text { Time fixed } \\
\text { effects }\end{array}$ & Yes & Yes & Yes & Yes & Yes & Yes & Yes & Yes & Yes & Yes \\
\hline 4. & Observations & 1559 & 1546 & 960 & 961 & 2387 & 2340 & 301 & 295 & 555 & 499 \\
\hline 5. & R-Squared & 0.33 & 0.09 & 0.47 & 0.10 & 0.24 & 0.08 & 0.34 & 0.13 & 0.13 & 0.09 \\
\hline 6. & Number of IDs & 51 & 51 & 31 & 31 & 79 & 78 & 10 & 10 & 19 & 17 \\
\hline
\end{tabular}

Robust standard errors underneath coefficient estimates.

$* * * p<0.01, * * p<0.05, * p<0.1$ 


\section{References}

Adrian, T., and H. S. Shin (2010). Financial Intermediaries and Monetary Economics. In: B. M. Friedman and M. Woodford (eds.), Handbook of Monetary Economics, New York, N.Y.: Elsevier.

Albertazzi, U., B. Becker, and M. Boucinha (2018). Portfolio rebalancing and the transmission of large-scale asset programmes: evidence from the euro area. ECB Working Paper 2125.

Albertazzi, U., A. Nobili, and F. Signoretti (2021). The Bank Lending Channel of Conventional and Unconventional Monetary Policy. Journal of Money, Credit, and Banking, forthcoming.

Altavilla, C., M. Bouchina, S. Holton, and S. Ongena (2018). Credit Supply and Demand in Unconventional Times. ECB Working Paper 2022.

Altavilla, C., L. Burlon, M. Giannetti, and S. Holton (2019). Is there a zero lower bound? The effects of negative policy rates on banks and firms. ECB Working Paper 2289.

Aramonte, S., S. J. Lee, and V. Stebunov ( 2015). Risk Taking and Low Longer- Term Interest Rates: Evidence from the U.S. Syndicated Loan Market. Finance and Economics Discussion Series 2015-068. Washington: Board of Governors of the Federal Reserve System,

Arce, O., Garcia-Posada, M., Mayordomo, S., and Ongena, S., (2018). Adapting Lending Policies in a "Negative for Long" Scenario," Bank of Spain Working Paper 1832 (Updated October 2020).

Arellano, M., and S. Bond (1991). Some Tests of Specification for Panel Data: Monte Carlo Evidence and An Application to Employment Equations. Review of Economic Studies, 58, $277-$ 297.

Avouyi-Dovi, S., G. Horny, P. Sevestre (2017). The Stability of Short-Term Interest Rates PassThrough in the Euro Area during the Financial Market and Sovereign Debt Crisis, Journal of Banking and Finance, 79, 74-94.

Basten, C., and M. Mariathasan (2018). How Banks Respond to Negative Interest Rates: Evidence from the Swiss Exemption Threshold. CESifo Working Paper 6901.

Babihuga, R., and M. Spaltro (2014). Bank Funding Costs for International Banks. IMF Working Paper No 14/71.

Bech, M., and A. Malkhozov (2016). How have Central Banks Implemented Negative Policy Rates? BIS Quartery Review, March 2016.

Belke, A., J. Beckmann, and F. Verheyen (2013). Interest Rate Pass-Through in the EMU: New Evidence from Nonliear Cointegration Techniques for Fully Harmonized Data, Journal of International Money and Finance, 37, 1-24.

Bernanke B. S., and A. Blinder (1988). Credit, Money, and Aggregate Demand. American Economic Review, 78(2), 435-439. 
Bernanke B. S., and A. Blinder (1992). The Federal Funds Rate and the Channels of Monetary Transmission. American Economic Review, 82(4), 901-921.

Billet, M., and J. Garfinkel (2004). Financial Flexibility and the Cost of External Finance for U.S. Bank Holding Companies. Journal of Money, Credit and Banking, Vol. 36(5), 827-852.

Blattner, T., and M. Joyce (2016). Net Debt Supply Shocks in the Euro Area and the Implications for QE, ECB Working Paper 1957.

Bonner, C. (2016). Preferential Regulatory Treatment and Banks' Demand for Government Bonds. Journal of Money, Credit and Banking, 48(6), 1195-1221.

Borio, C., and L. Gambacorta (2017). Monetary policy and bank lending in a low interest rate environment: diminishing effectiveness?, BIS Working Paper 612.

Borio, C., and H. Zhu (2008). Capital Regulation, Risk-taking and Monetary Policy: A missing link in the transmission mechanism? BIS Working Paper 268.

Bottero, M., Minoiu, C., Peydro, J.L., Polo, A., Presbitero, A.F., Sette, E. (2019). Negative Monetary Policy Rates and Portfolio Rebalancing: Evidence from Credit Register Data. IMF Working Paper 19/44.

Boungou, W. (2020). Negative Interest Rates Policy and Banks’ Risk-Taking: Empirical Evidence, Economics Letters, 186, 1-3.

Bräuning, F., and B. Wu (2017). ECB Monetary Policy Transmission During Normal and Negative Interest Rate Periods. Available at SSRN.

Brunnermeier, M. K., and Y. Koby (2017). The Reversal Interest Rate: An Effective Lower Bound on Monetary Policy. Unpublished, Princeton University, Princeton, NJ.

Bubeck, J., A. Maddaloni, and J.L. Peydró (2020). Negative Monetary Policy Rates and Systemic Banks' Risk-Taking: Evidence from the Euro Area Securities Register, Journal of Money, Credit, and Banking, Supplement to Vol. 52, 197-231.

Carpenter, S., S. Demiralp and J. Eisenschmidt (2014). The effectiveness of non-standard monetary policy in addressing liquidity risk during the financial crisis: The experience of the Federal Reserve and the European Central Bank, Journal of Economic Dynamics and Control, 43, 107-129.

Cornett, M. M., J. J. McNutt, P. E. Strahan, and H. Tehranian (2011). Liquidity Risk Management and Credit Supply in the Financial Crisis. Journal of Financial Economics, 101, 297-312.

Dell'Ariccia, G., L. Laeven, and G. Suarez (2017). Bank Leverage and Monetary Policy's RiskTaking Channel: Evidence from the United States. Journal of Finance, 72(2), 613-654.

Drechsler, I, A. Savov, and P. Schnabl (2017a). The Deposit Channel of Monetary Policy. Quarterly Journal of Economics, 132(4), 1819-1876. 
Drechsler, I, A. Savov, and P. Schnabl (2020). Banking on Deposits: Maturity Transformation without Interest Rate Risk, Journal of Finance, forthcoming.

ECB (2020). The euro area bank lending survey - First quarter of 2020, April. Available at https://www.ecb.europa.eu/stats/ecb_surveys/bank_lending_survey/pdf/ecb.blssurvey2020q1 17 a1b2b7d2.en.pdf

Eggertsson, G., E. Juelsrud, and E. Wold (2017). Are Negative Nominal Interest Rates Expansionary? NBER Working Paper 24039

Eisenschmidt, J., D. Kedan, M. Schmitz, R. Adalid, and P. Papsdorf (2017). The Eurosystem's Asset Purchase Programme and TARGET balances. ECB Occasional Paper 196.

Eisenschmidt, J., and Smets, F. (2019). Negative Interest Rates: Lessons from the Euro Area. in A. Aguirre, M. Brunnermeier, D. Saravia (ed.) Monetary Policy and Financial Stability:

Transmission Mechanisms and Policy Implications, edition 1, volume 26, chapter 2, 13-42, Central Bank of Chile.

Ennis, H. M., and A. L. Wolman (2015). Large Excess Reserves in the United States: A View from the Cross-section of Banks. International Journal of Central Banking, 11, 251-289.

Friedman, M., and A. Schwartz (1963). Money and Business Cycles. Review of Economics and Statistics, 45, 32-64.

Gambacorta, L., B. Hofmann, and G. Peersman (2014). The Effectiveness of Unconventional Monetary Policy at the Zero Lower Bound: A Cross Country Analysis, Journal of Money Credit and Banking, 46, 615-642.

Gennaioli, N., A. Martin, and S. Rossi (2014). Sovereign Default, Domestic Banks, and Financial Institutions. Journal of Finance, 69(2), 819-866.

Grandi, P. and M. Guille (2020). The Upside Down: French Banks, Deposits and Negative Policy Rates. Université Paris II Working Paper.

Grisse, C., S. Krogstrup, and S. Schumacher (2017). Lower Bound Beliefs and Long-Term Interest Rates. International Journal of Central Banking, 50, 165-202.

Hamerly, G., and C. Elkan (2002). Alternatives to the k-means algorithm that find better clusterings. Unpublished manuscript.

Heider, F., F. Saidi, and G. Schepens (2019). Life Below Zero: Bank Lending under Negative Rates, Review of Financial Studies, 32 (10), 3728-3761.

Hong, G.H., and J. Kandrac (2018). Pushed Past the Limit? How Japanese Banks Reacted to Negative Interest Rates. IMF Working Paper 18/131.

Horvath, R., J. Kotlebova, M. Siranova (2018). Interest Rate Pass-Through in the Euro Area: Financial Fragmentation, Balance Sheet Policies and Negative Rates, Journal Of Financial Stability, 36, 12-21. 
Hristov, N., O. Hulsewig, and T. Wollmershauser (2014). The Interest Rate Pass-Through in the Euro Area during the Global Financial Crisis, Journal of Banking and Finance, 48, 104-119.

Jackson, H. (2015). The International Experience with Negative Policy Rates. Bank of Canada Staff Discussion Paper 2015-13.

Jimenez, G., S. Ongena, J. L. Peydro, and J. Saurina (2012). Credit Supply and Monetary Policy: Identifying the Bank Balance-Sheet Channel with Loan Applications. American Economic Review, 102(5), 2301-2326.

Kashyap, A. K, and J. C. Stein (2000). What do a million observations on banks say about the transmission of monetary policy?. American Economic Review 90(3), 407-428.

Kiley, M., and J. Roberts (2017). Monetary Policy in a Low Interest Rate World, Brookings Papers on Economic Activity, Spring 2017, 317-396.

Krishnamurthy, A., and A. Vissing-Jorgensen (2011). The Effects of Quantitative Easing on Interest Rates: Channels and Implications for Policy. Brookings Papers on Economic Activity, Fall 2011, 215-265.

Lemke, W., and A.L. Vladu (2017). Below the Zero Lower Bound: A Shadow-Rate Term Structure Model for the Euro Area. ECB Working Paper 1991.

Lopez, J., A. Rose, and M. Spiegel (2020). Why Have Negative Nominal Interest Rates Had Such a Small Effect on Bank Performance? Cross Country Evidence, European Economic Review, 124, 1-17.

Lucas, A., J Schaumburg, and B. Schwaab (2019). Bank Business Models at Zero Interest Rates. Journal of Business and Economics Statistics. 37(3), 542-555.

Molyneux, P., A. Reghezza, R. Xie (2019). Bank Margins and Profits in a World of Negative Rates, Journal of Banking and Finance, 107, 1-20.

Nucera, F., A. Lucas, J. Schaumburg, and B. Schwaab (2017). Do Negative Interest Rates Make Banks Less Safe, Economics Letters, 159, 112-115.

Judson, R. A., and A. L. Owen (1999). Estimating dynamic panel data models: a guide for macroeconomists. Economics Letters, 65, 9-15.

Popov, A., and N. Van Horen (2013). The Impact of Sovereign Debt Exposure on Bank Lending: Evidence from the European Debt Crisis. DNB Working Paper 382.

Ryan, E. and K. Whelan (2019). Quantitative Easing and the Hot Potato Effect: Evidence from Euro Area Banks, CEPR Working Paper 13499.

Ulate, M. (2021). Going Negative at the Zero Lower Bound: The Effects of Negative Nominal Interest Rates. American Economic Review, 111(1), 1-40.

Urbschat, F. (2018). The Good, the Bad, and the Ugly: Impact of Negative Interest Rates and QE on the Profitability and Risk-Taking of 1600 German Banks, Munich Discussion Paper 2018-7. 
Ward, J. H. (1963). Hierarchical Grouping to Optimize Objective Function. Journal of the American Statistical Association 58, 236-244.

Witmer, J., and J. Yang (2015). Estimating Canada's Effective Lower Bound. Bank of Canada Staff Analytical Note 2015-2.

Wu, J. C., and F. D. Xia (2017). Time-Varying Lower Bound of Interest Rates in Europe. Unpublished manuscript. 


\section{Appendix 1}

Table A1.1: Exogeneity of the Excess Liquidity Ratio

Dependent variable: $E L$ ratio $_{i, t}=\frac{E L_{i, t}}{\operatorname{Asset}_{i, t-1}}$

\begin{tabular}{c|c|c}
\hline \hline 1. & Avg_EL & $0.882^{* * *}$ \\
2. & RR $_{i . t-1}$ & 0.055 \\
& & $-0.013^{* * *}$ \\
3. & ${\text { Liquidity } \text { Ratio }_{i, t-1}}$ & 0.003 \\
& & -0.002 \\
4. & Leverage Ratio & 0.005 \\
& & -0.008 \\
5. & $r_{i . t-1}^{\text {loan }}$ & 0.021 \\
& & $-0.001^{* *}$ \\
\hline 6. & Time fixed effects & 0.000 \\
7. & Observations & Yes \\
8. & R-Squared & 0543 \\
9. & Number of IDs & 0.30 \\
\hline \hline
\end{tabular}

Robust (White period) standard errors underneath coefficient estimates.

$* * * \mathrm{p}<0.01, * * \mathrm{p}<0.05, * \mathrm{p}<0.1$

Regression includes a constant and time fixed effects. 
Table A1. 2

High EL vs. Low EL Banks (pre-NIRP)

\begin{tabular}{|l|l|l|l|l|l|l|}
\hline VARIABLE & & $\begin{array}{l}\text { Number } \\
\text { of Banks }\end{array}$ & $\begin{array}{l}\text { Number of } \\
\text { Observations }\end{array}$ & Mean & Std.dev & t-stat \\
\hline \multirow{2}{*}{ 1.Retail ratio in \% } & Bottom & 83 & 2,065 & 30.53 & 25.72 & 16.1 \\
\cline { 2 - 7 } & Top & 84 & 2,252 & 18.95 & 21.50 & \\
\hline \multirow{2}{*}{ 2. Assets } & Bottom & 83 & 2,091 & 50503 & 74780 & -17.34 \\
\cline { 2 - 7 } & Top & 84 & 2,329 & 119604 & 167907 & \\
\hline \multirow{2}{*}{ 4. Liquidity Ratio } & Bottom & 83 & 2,090 & 8.27 & 9.08 & 4.31 \\
\cline { 2 - 7 } & Top & 84 & 2,307 & 7.01 & 10.09 & \\
\hline \multirow{2}{*}{ 5.Wholesale funding in \% } & Bottom & 83 & 2,035 & 35.89 & 21.30 & 1.92 \\
\cline { 2 - 7 } & Top & 84 & 2,218 & 26.00 & 231.58 & \\
\hline \multirow{2}{*}{ 6. EL Ratio } & Tottom & 83 & 2,066 & 37.50 & 27.42 & 9.75 \\
\hline $\begin{array}{l}\text { 7. Liquidity Ratio } \\
\text { (including EL) }\end{array}$ & Bottom & 84 & 2,272 & 29.86 & 24.21 & \\
\cline { 2 - 7 } & Top & 84 & 2,090 & 0.063 & 0.44 & -2.21 \\
\cline { 2 - 7 } & Bottom & 83 & 1,928 & 32.59 & 19.22 & -0.02 \\
\cline { 2 - 7 } & Top & 84 & 1,732 & 32.60 & 19.73 & \\
\hline
\end{tabular}

High EL vs. Low EL Banks (NIRP)

\begin{tabular}{|l|l|l|l|l|l|l|}
\hline VARIABLE & & $\begin{array}{l}\text { Number } \\
\text { of Banks }\end{array}$ & $\begin{array}{l}\text { Number of } \\
\text { Observations }\end{array}$ & Mean & Std.dev & t-stat \\
\hline \multirow{2}{*}{ 1.Retail ratio in $\%$} & Bottom & 83 & 1,085 & 32.72 & 25.97 & 10.51 \\
\cline { 2 - 7 } & Top & 84 & 1,226 & 21.80 & 23.91 & \\
\hline \multirow{2}{*}{ 2. Assets } & Bottom & 83 & 1,087 & 51938 & 84682 & -12.27 \\
\cline { 2 - 7 } & Top & 84 & 1,227 & 127930 & 187970 & \\
\hline \multirow{2}{*}{ 3. Leverage Ratio } & Bottom & 83 & 1,085 & 10.00 & 26.32 & -0.13 \\
\cline { 2 - 7 } & Top & 84 & 1,226 & 10.11 & 11.85 & \\
\hline \multirow{2}{*}{ 4. Liquidity Ratio } & Bottom & 83 & 1,070 & 36.99 & 22.64 & 6.97 \\
\cline { 2 - 7 } & Top & 84 & 1,181 & 25.43 & 49.84 & \\
\hline \multirow{2}{*}{ 5.Wholesale funding in \% } & Bottom & 83 & 1,085 & 31.17 & 38.58 & 4.95 \\
\cline { 2 - 7 } & Top & 84 & 1,226 & 24.64 & 23.94 & \\
\hline \multirow{2}{*}{ 6. EL Ratio } & Bottom & 83 & 1,085 & 0.55 & 2.38 & -9.36 \\
\cline { 2 - 7 } & Top & 84 & 1,226 & 14.42 & 48.74 & \\
\hline \multirow{2}{*}{$\begin{array}{l}\text { 7. Liquidity Ratio } \\
\text { (including EL) }\end{array}$} & Bottom & 83 & 1,110 & 33.81 & 21.42 & 1.28 \\
\cline { 2 - 7 } & Top & 84 & 1,018 & 32.66 & 19.89 & \\
\hline
\end{tabular}

High EL and Low EL banks are defined as those banks in the top tercile and bottom tercile based on average EL level in the year before NIRP respectively. 
Table A1. 3: High vs. Low EL Banks (High Deposit Sample)

High EL vs. Low EL Banks (pre-NIRP)

\begin{tabular}{|l|l|l|l|l|l|l|}
\hline VARIABLE & & $\begin{array}{l}\text { Number } \\
\text { of Banks }\end{array}$ & $\begin{array}{l}\text { Number of } \\
\text { Observations }\end{array}$ & Mean & Std.dev & t-stat \\
\hline \multirow{2}{*}{ 1.Retail ratio in \% } & Bottom & 35 & 926 & 48.18 & 14.20 & 7.34 \\
\cline { 2 - 7 } & Top & 36 & 972 & 42.51 & 18.97 & \\
\hline \multirow{2}{*}{ 2. Assets } & Bottom & 35 & 926 & 36061 & 44226 & -12.84 \\
\cline { 2 - 7 } & Top & 36 & 983 & 91929 & 125220 & \\
\hline \multirow{2}{*}{ 4. Leverage Ratio } & Bottom & 35 & 926 & 7.50 & 3.04 & 1.80 \\
\cline { 2 - 8 } & Top & 36 & 972 & 7.24 & 3.19 & \\
\hline \multirow{2}{*}{ 5.Wholesale funding in \% } & Bottom & 35 & 904 & 30.12 & 14.95 & -1.75 \\
\cline { 2 - 7 } & Top & 36 & 872 & 31.46 & 17.91 & \\
\hline \multirow{2}{*}{ 6. EL Ratio } & Tottom & 35 & 924 & 22.54 & 11.64 & 2.22 \\
\hline \multirow{2}{*}{$\begin{array}{l}\text { 7. Liquidity Ratio } \\
\text { (including EL) }\end{array}$} & Bottom & 36 & 970 & 21.32 & 12.47 & \\
\cline { 2 - 7 } & Top & 36 & 972 & 0.05 & 0.30 & -13.86 \\
\hline
\end{tabular}

High EL vs. Low EL Banks (NIRP)

\begin{tabular}{|l|l|l|l|l|l|l|}
\hline VARIABLE & & $\begin{array}{l}\text { Number } \\
\text { of Banks }\end{array}$ & $\begin{array}{l}\text { Number of } \\
\text { Observations }\end{array}$ & Mean & Std.dev & t-stat \\
\hline \multirow{2}{*}{ 1.Retail ratio in \% } & Bottom & 35 & 515 & 51.86 & 12.95 & 1.21 \\
\cline { 2 - 7 } & Top & 36 & 522 & 50.69 & 17.86 & \\
\hline \multirow{2}{*}{ 2. Assets } & Bottom & 35 & 515 & 40114 & 50305 & -9.42 \\
\cline { 2 - 7 } & Top & 36 & 523 & 103146 & 143355 & \\
\hline \multirow{2}{*}{ 3. Leverage Ratio } & Bottom & 35 & 515 & 9.02 & 3.22 & 0.53 \\
\cline { 2 - 8 } & Top & 36 & 522 & 8.90 & 3.86 & \\
\hline \multirow{2}{*}{ 4. Liquidity Ratio } & Bottom & 35 & 500 & 27.30 & 11.78 & -2.37 \\
\cline { 2 - 7 } & Top & 36 & 462 & 29.32 & 14.64 & \\
\hline \multirow{3}{*}{ 6. Wholesale funding in $\%$} & Bottom & 35 & 515 & 15.64 & 9.57 & 4.12 \\
\cline { 2 - 7 } & Top & 36 & 522 & 13.35 & 8.29 & \\
\hline \multirow{2}{*}{$\begin{array}{l}\text { 7. Liquidity Ratio } \\
\text { (including EL) }\end{array}$} & Bottom & 35 & 515 & 0.32 & 0.96 & -16.46 \\
\cline { 2 - 7 } & Top & 36 & 522 & 3.27 & 3.95 & \\
\cline { 2 - 7 } & Bottom & 35 & 488 & 33.44 & 19.94 & 6.84 \\
\cline { 2 - 7 } & Top & 36 & 454 & 25.55 & 14.90 & \\
\hline
\end{tabular}

High EL and Low EL banks are defined as those banks in the top tercile and bottom tercile based on average EL level in the year before NIRP respectively. High deposit banks are defined as those banks whose average retail deposit ratios in the year before NIRP were above the median, consistent with the baseline regressions. 
Table A1. 4: High vs. Low EL Banks (Low Deposit Sample)

High EL vs. Low EL Banks（pre-NIRP)

\begin{tabular}{|c|c|c|c|c|c|c|}
\hline VARIABLE & & $\begin{array}{l}\text { Number } \\
\text { of Banks }\end{array}$ & $\begin{array}{l}\text { Number of } \\
\text { Observations }\end{array}$ & Mean & Std.dev & t-stat \\
\hline \multirow{2}{*}{ 1.Retail ratio in \% } & Bottom & 35 & 858 & 3.86 & 6.49 & -13.89 \\
\hline & Top & 36 & 964 & 9.55 & 10.34 & \\
\hline \multirow{2}{*}{ 2. Assets } & Bottom & 35 & 884 & 75491 & 3339 & -14.68 \\
\hline & Top & 36 & 1,008 & 183658 & 6247 & \\
\hline \multirow{2}{*}{ 3. Leverage Ratio } & Bottom & 35 & 883 & 9.38 & 11.40 & 0.56 \\
\hline & Top & 36 & 997 & 9.06 & 13.34 & \\
\hline \multirow{2}{*}{ 4. Liquidity Ratio } & Bottom & 35 & 861 & 42.04 & 24.25 & 6.34 \\
\hline & Top & 36 & 986 & 36.06 & 15.92 & \\
\hline \multirow{2}{*}{ 5. Wholesale funding in \% } & Bottom & 35 & 872 & 58.79 & 26.42 & 16.80 \\
\hline & Top & 36 & 986 & 39.29 & 23.60 & \\
\hline \multirow{2}{*}{ 6. EL Ratio } & Bottom & 35 & 883 & 0.10 & 0.72 & -8.89 \\
\hline & Top & 36 & 997 & 1.77 & 5.52 & \\
\hline \multirow{2}{*}{$\begin{array}{l}\text { 7. Liquidity Ratio } \\
\text { (including EL) }\end{array}$} & Bottom & 35 & 776 & 31.35 & 16.75 & -4.46 \\
\hline & Top & 36 & 714 & 36.21 & 24.83 & \\
\hline
\end{tabular}

\section{High EL vs. Low EL Banks (NIRP)}

\begin{tabular}{|l|l|l|l|l|l|l|}
\hline VARIABLE & & $\begin{array}{l}\text { Number } \\
\text { of Banks }\end{array}$ & $\begin{array}{l}\text { Number of } \\
\text { Observations }\end{array}$ & Mean & Std.dev & t-stat \\
\hline \multirow{2}{*}{ 1.Retail ratio in \% } & Bottom & 35 & 478 & 5.07 & 8.16 & -9.25 \\
\cline { 2 - 7 } & Top & 36 & 524 & 10.45 & 10.04 & \\
\hline \multirow{2}{*}{ 2. Assets } & Bottom & 35 & 479 & 74104 & 111974 & -10.11 \\
\cline { 2 - 7 } & Top & 36 & 524 & 188631 & 223653 & \\
\hline \multirow{2}{*}{ 3. Leverage Ratio } & Bottom & 35 & 478 & 11.69 & 13.68 & -1.44 \\
\cline { 2 - 7 } & Top & 36 & 524 & 13.05 & 15.86 & \\
\hline \multirow{2}{*}{ 4. Liquidity Ratio } & Bottom & 35 & 478 & 45.64 & 25.58 & 11.97 \\
\cline { 2 - 7 } & Top & 36 & 524 & 29.84 & 15.35 & \\
\hline \multirow{2}{*}{ 5.Wholesale funding in \% } & Bottom & 35 & 478 & 52.86 & 30.54 & 10.99 \\
\cline { 2 - 7 } & Top & 36 & 524 & 33.99 & 23.64 & \\
\hline \multirow{2}{*}{ 6. EL Ratio } & Bottom & 35 & 478 & 0.76 & 3.07 & -15.63 \\
\cline { 2 - 7 } & Top & 36 & 524 & 4.90 & 5.00 & \\
\hline \multirow{2}{*}{$\begin{array}{l}\text { 7. Liquidity Ratio } \\
\text { (including EL) }\end{array}$} & Bottom & 35 & 470 & 31.40 & 16.74 & -4.61 \\
\cline { 2 - 7 } & Top & 36 & 439 & 37.36 & 22.04 & \\
\hline
\end{tabular}

High EL and Low EL banks are defined as those banks in the top tercile and bottom tercile based on average EL level in the year before NIRP respectively. Low deposit banks are defined as those banks whose average retail deposit ratios in the year before NIRP were below the median. 


\section{Appendix 2}

In the DiD specification that is considered in the main text, the exposure to treatment is measured as average EL holdings in the year before NIRP, which is constant over time. In this section, we consider an alternative specification that allows us to consider the time varying dimension of our exposure to treatment variable. We specify an equation that is similar to the loan regression in Cornett et al. (2011), to estimate the impact of NIRP on bank loans.

$$
\begin{aligned}
Y_{i, t}=\mathrm{T}_{\mathrm{t}}+\mathrm{B}_{\mathrm{i}} & +\beta_{0} \mathrm{Y}_{i, \mathrm{t}-1}+\beta_{1} \mathrm{EL}_{\mathrm{i}, \mathrm{t}-1}\left(1-\mathrm{D}^{\mathrm{NIR}}\right)+\beta_{2} \mathrm{EL}_{\mathrm{i}, \mathrm{t}-1} D^{N I R} \\
& +\beta_{3} \mathrm{EL}_{\mathrm{i}, \mathrm{t}-1}\left(1-D^{N I R}\right) R R_{i, t-1}+\beta_{4} E L_{i, t-1} D^{N I R} R R_{i, t-1} \\
& +\beta_{5}\left(1-D^{N I R}\right) R R_{i, t-1}+\beta_{6} D^{N I R} R R_{i, t-1} \\
& +\beta_{7} \text { Liquidity ratio }_{i, t-1} \\
& +\beta_{8} \text { Leverage ratio }_{i, t-1}+\beta_{9} \text { BLS demand }_{t} \\
& +\beta_{10} r_{i, t-1}^{\text {Loan }}+\beta_{11} \text { Unemployment }_{j, t-1}+\varepsilon_{i, t}
\end{aligned}
$$

where $Y_{i, t}={\text { Loan } \text { ratio }_{i, t}}=\frac{\text { Loans }_{i, t}}{\text { Assets }_{i, t-1}}$ is the same dependent variable used in our baseline

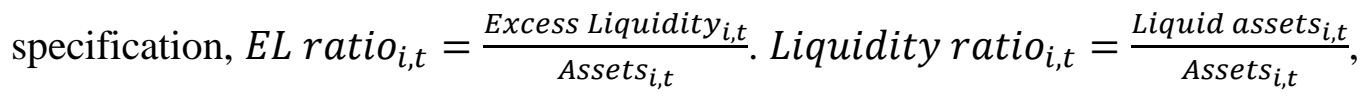
Leverage ratio $_{i, t}=\frac{\left({\text { Capital }+ \text { Reserves }_{i, t}}_{\text {Rset }_{i, t}}\right.}{\text { Ass }_{i, t}}=\frac{\text { Retail Deposits }_{i, t}}{\text { Assets }_{i, t}}$. The following variables are scaled by $1 / 100$ for comparable coefficient estimates: $B L S$ demand $_{j, t}$ is a proxy for loan demand measured from the BLS survey, ${ }^{27} r_{i, t-1}^{\text {Loan }}$ is composite loan rate, and Unemployment ${ }_{j, t-1}$ is the unemployment rate. The subscript $i$ denotes individual bank $i$, and $j$ is the country where the bank is located in.

\footnotetext{
${ }^{27}$ Note that country results for the BLS are used, which ensures cross-sectional variation across countries and therefore does not lead to collinearity problems with the time fixed effects.
} 
Liquid assets are defined as the sum of interbank lending, holdings of government bonds, holdings of debt securities issued by MFIs, holdings of debt securities issued by the private sector, and holdings of equity. Retail deposits are defined as deposits (of all maturities) of households and $r_{i}^{\text {Loan }}$ is the composite lending rate of bank $i$.

We control for the potential endogeneity between macroeconomic variables, bank balance sheet components and the dependent variable by lagging the right hand side variables, which is standard practice in the literature (see e.g. Cornett et al., 2011; Kashyap and Stein, 2000). Carpenter et al. (2014) provide further evidence of a lagged adjustment of loan demand to economic activity. In the robustness section, we also consider a "difference in differences" methodology to address endogeneity issues and illustrate that our results are robust under this approach.

Our strategy for identifying the effects of the NIRP period on bank loan issuance is operationalised in equation (A.1) by interacting the EL ratio with a dummy variable for the NIRP period and by interacting EL with Retail Ratio (RR), which is our measure of banks' retail deposit intensity. If banks are indeed more motivated to turn their EL into loans during the NIRP period, we expect $\beta_{2}>\beta_{1}$. Furthermore, if this response is proportional to their holdings of retail deposits, then we expect $\beta_{2}+\beta_{4}>\beta_{1}+\beta_{3}$.

Equation (A.1) is estimated as a panel fixed effects model. We include bank fixed effects $\left(B_{i}\right)$ to control for unobservable time-invariant bank-specific factors that affect the decision to extend loans. ${ }^{28}$ Moreover, our specifications include time fixed effects $\left(T_{t}\right)$ to control for aggregate shocks. The errors are clustered at the bank level. The estimation sample covers the period from 2010.Q1 to 2017.Q3, consistent with the main text. The relatively long time

\footnotetext{
${ }^{28}$ Pooled OLS estimates without fixed effects (not reported in the paper) as well as a model that replaces bank fixed effects with country fixed effects give qualitatively similar results.
} 
dimension of our dataset with 43 quarters does not require the use of an Arellano and Bond (1991) type of estimator to address the dynamic structure. ${ }^{29}$ We classify banks into three business models: high, medium, and low retail deposit intensity, based on the size of their retail deposits/assets ratios, using the 33rd and 66th percentiles to split the sample.

Banks that have more funding through retail deposits are more likely to issue loans $\left(\beta_{5}, \beta_{6}>0\right)$. Banks that have more liquid balance sheets or higher capital ratios are expected to issue more loans as well $\left(\beta_{7}, \beta_{8}>0\right)$. An increase in demand should increase the volume of loans $\left(\beta_{9}>0\right)$. We also control for demand with the unemployment rate. An increase in the unemployment rate should lead to a decline in loan issuance $\left(\beta_{11}<0\right)$.

Table A2-1a shows the estimation results. We drop the $\mathrm{i}$ and $\mathrm{j}$ indices to simplify the notation. EL is lagged in order to avoid potential endogeneity. The flow nature of our dependent variable with minimal autocorrelation further helps in eliminating any remaining endogeneity that may arise in a dynamic set up. ${ }^{30}$ The coefficient associated with EL (rows 2-3) shows the impact of EL on loans, evaluated when $R R=0$. The negative and significant coefficient for the high deposit banks (column 3, row 3) likely reflects the economic situation post crisis. This was an environment with parts of the euro area banking sector still de-leveraging while monetary policy reacted to this situation with expansionary measures that led to rising EL while loans for some banks in some countries continued to decline.

\footnotetext{
${ }^{29}$ The Arellano-Bond (1991) estimator is designed for short panels. In long panels, a shock to the cross-sectional fixed effect declines with time and the correlation of the lagged dependent variable with the error term becomes insignificant. Judson and Owen (1999) use Monte-Carlo simulations and show that the so-called "Nickell bias" is no longer significant for panels where the time dimension is larger than 30 .

${ }^{30}$ Endogeneity would arise if there is reverse causality from bank loans to EL. There is, however, no reason to expect that the flow of loans in period $t$ would influence the stock of EL at the end of the previous period $t$ - 1 . Our framework does indeed suggest that banks that extend more loans would, ceteris paribus, reduce their EL, which would induce a negative bias. To the extent that lagging EL and utilizing flow data for loans does not completely eliminate this bias, our results will err on the conservative side and underestimate the transmission channel that we aim to identify.
} 
As described in the main text, however, there are differences among banks in terms of their exposure to EL. In particular, banks are exposed to a less favourable situation when RR $>0$, which should motivate them to convert their EL into loans, as reflected by the positive and significant coefficient associated with $\mathrm{EL} \times \mathrm{RR}$ during NIRP (column 3, row 5) for high deposit banks. This is consistent with the goal of NIRP and in line with our stylized description of cross sectional differences in Figure 5.

Table A2-1b displays the relevant hypothesis tests. To ascertain whether the NIRP effect is indeed special, it is necessary to jointly consider the coefficients on the double and triple interaction. The first row in Table A2-1b tests whether the joint EL effect is significant in the period before NIRP. The second row tests the same effect for NIRP. The one-sided hypothesis tests whether the joint effect is positive. We note that for the high deposit banks, there is a significant and positive impact such that higher values of EL are associated with more loan extensions. The third row compares the relative magnitudes of the coefficient estimates during the two periods. We observe that the observed response is indeed different (two sided hypothesis) and the response during NIRP period is larger (one sided hypothesis) for medium and high deposit banks.

Based on the results presented in Table A2-1a, the NIRP effect corresponds on average to 12 percent of the quarterly lending by high retail banks during the NIRP period. ${ }^{31}$ This finding is rather similar to the 15 percent increase that is obtained with DiD estimation reported in the main text.

\footnotetext{
${ }^{31}$ In order to calculate the economic significance of our results, we calculate the ratio: $\frac{E \operatorname{Lratio}_{i}\left(\beta_{2}+\beta_{4} R R_{i}\right)}{\operatorname{Loan~flow~}_{i}}$ where Loan flow,$R R_{\mathrm{i}}$ and EL ratio $\mathrm{i}_{\mathrm{i}}$ are the sample average values during NIRP and $\beta_{\mathrm{i}}$ is the coefficient estimate from equation (1).
} 
The results for our control variables are generally in line with our expectations. Banks that have more retail deposit funding or more liquid balance sheets tend to issue more loans (rows 6-8). A decrease in demand, captured by the increase in the unemployment rate, leads to less loan extension as expected (row 12).

\section{Security holdings}

We use the following equation, similar to our loan equation in the previous section:

$$
\begin{aligned}
Y_{i, t}=\mathrm{T}_{\mathrm{t}}+\mathrm{B}_{\mathrm{i}}+ & \beta_{0} \mathrm{Y}_{i, \mathrm{t}-1}+\beta_{1} \mathrm{EL}_{\mathrm{I}, \mathrm{t}-1}\left(1-\mathrm{D}^{\mathrm{NIR}}\right)+\beta_{2} \mathrm{EL}_{\mathrm{i}, \mathrm{t}-1} D^{N I R} \\
& +\beta_{3} \mathrm{EL}_{\mathrm{i}, \mathrm{t}-1}\left(1-D^{N I R}\right) R R_{i, t-1}+\beta_{4} E L_{i, t-1} D^{N I R} R R_{i, t-1}+\beta_{5}\left(1-D^{N I R}\right) R R_{i, t-1} \\
& +\beta_{6} D^{N I R} R R_{i, t-1}+\beta_{7} \text { Liquidity ratio }_{i, t-1}+\beta_{8} \text { Leverage ratio }_{i, t-1} \\
& +\beta_{9}\left(r_{i, t-1}^{\text {Loan }}-r_{j, t-1}^{10 y}\right)+\beta_{10} \Delta r_{j, t-1}^{10 y} D^{2014}+\beta_{11} \log \left(\text { Assets }_{i, t-1}\right. \\
& +\beta_{12} \text { Unemployment }_{j, t-1}+\varepsilon_{i t}
\end{aligned}
$$

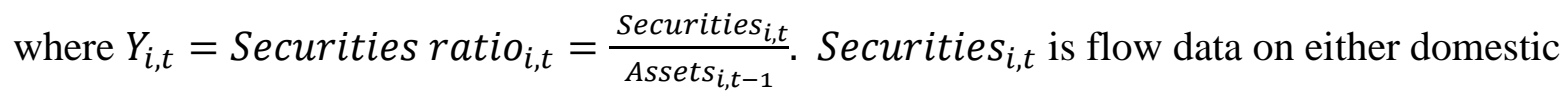
government bonds or non-domestic government bonds. The variable $r_{j}^{10 y}$ denotes the yield on the 10 -year government bonds issued in country $j$, i.e. the country in which the respective bank is located. We interact this variable with a dummy variable after the fourth quarter of 2014 in order to control for the negative interest rate environment. The loan rate as well as the spread of the loan rate with respect to 10 -year government bond rate is scaled by $1 / 100$.

Similar to our logic in the previous section, if banks are more motivated to buy bonds with their EL during NIRP, we expect $\beta_{2}>\beta_{1}$. Furthermore, if this behaviour is more pronounced for higher levels of retail ratios, we expect $\beta_{2}+\beta_{4}>\beta_{1}+\beta_{3}$. 
Tables A2-2 and A2-3 report the estimation results for domestic government bonds, nondomestic government bonds. We do not observe a significant increase in any type of security holding on average during NIRP consistent with our results in the main text.

There is a significant reaction to the opportunity cost of holding non-domestic government bonds (Table A2-3a, row 11).

\section{Wholesale funding}

We consider an empirical specification that is similar to the earlier ones:

$$
\begin{aligned}
Y_{i, t}=\mathrm{T}_{\mathrm{t}}+\mathrm{B}_{\mathrm{i}}+ & \beta_{0} \mathrm{Y}_{i, \mathrm{t}-1}+\beta_{1} \mathrm{EL}_{\mathrm{i}, \mathrm{t}-1}\left(1-\mathrm{D}^{\mathrm{NIR}}\right)+\beta_{2} \mathrm{EL}_{\mathrm{i}, \mathrm{t}-1} D^{N I R} \\
& +\beta_{3} \mathrm{EL}_{\mathrm{i}, \mathrm{t}-1}\left(1-D^{N I R}\right) R R_{i, t-1}+\beta_{4} E L_{i, t-1} D^{N I R} R R_{i, t-1} \\
& +\beta_{5}\left(1-D^{N I R}\right) R R_{i, t-1}+\beta_{6} D^{N I R} R R_{i, t-1}+\beta_{7} \text { Liquidity ratio }_{i, t-1} \\
& +\beta_{8} \text { Leverage ratio }_{i, t-1}+\beta_{9} \text { BLS } \text { demand }_{t} \\
& +\beta_{10}\left(r_{j, t-1}^{2 y}-r_{i, t-1}^{\text {Deposit }^{2}}\right)+\beta_{11} \text { Unemployment }_{j, t-1}+\varepsilon_{i t}
\end{aligned}
$$

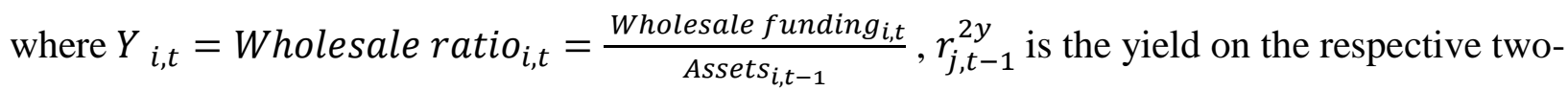
year sovereign bond, $r_{i, t-1}^{\text {Deposit }}$ is the composite deposit rate of each bank. The spread is scaled by $1 / 100$.

The spread between the two-year sovereign bond rate and the deposit rate is a proxy to capture the relative cost of wholesale funding. Billett and Garfinkel (2004) note that banks' choice between insured and uninsured funding depends on the differential rates charged in the two markets. An increase in this spread reflects an increase in the cost of wholesale funding and hence implies a negative coefficient: $\beta_{10}<0$. If banks are more motivated to use their EL to pay back their wholesale borrowing during the NIRP period and if this motivation is further 
reinforced by the bank's business model, then we expect $\beta_{2}<\beta_{1}$. Furthermore, if this behaviour is more pronounced for high deposit holders, we expect $\beta_{2}+\beta_{4}<\beta_{1}+\beta_{3}$.

Variables such as the leverage ratio indirectly control for banks' unsecured funding costs (Babihuga and Spaltro, 2014) as banks with better capitalisation (i.e. a higher leverage ratio as defined here) should have lower wholesale funding costs and are, therefore, more likely to tap wholesale funding resources: $\beta_{8}>0$.

Table A2-4 shows the estimation results, which does not indicate a significant adjustment during NIRP. Looking at the other control variables, banks that have higher levels of liquid assets tend to rely on less wholesale funding as expected. 
Table A2-1a: Effects of NIRP on Bank Loans

Dependent variable: Ratio of winsorized loan flow

\begin{tabular}{|c|c|c|c|c|}
\hline & Variables & (1) & (2) & (3) \\
\hline 1. & Lagged dependent variable & $0.150 * *$ & 0.006 & $0.091^{* *}$ \\
\hline 2. & EL ratio $_{\mathrm{t}-1} \times\left(1-\mathrm{D}^{\mathrm{NIK}}\right)$ & $-0.050 * * *$ & 0.117 & -0.113 \\
\hline 3. & EL ratio $_{\mathrm{t}-1} \times \mathrm{D}^{\mathrm{NIR}}$ & -0.039 & 0.032 & $-0.154 * *$ \\
\hline 4. & $\begin{aligned} \text { EL ratio }_{\mathrm{t}-1} \times & \left(1-\mathrm{D}^{\mathrm{NIK}}\right) \\
& \times \mathrm{RR}_{\mathrm{t}-1}\end{aligned}$ & 0.965 & $-0.841^{*}$ & 0.199 \\
\hline 5. & EL ratio $_{\mathrm{t}-1} \mathrm{D}^{\mathrm{NIR}} \times \mathrm{RR}_{\mathrm{t}-1}$ & 0.336 & -0.069 & $0.358 * *$ \\
\hline 6. & $\mathrm{RR}_{\mathrm{t}-1} \times\left(1-\mathrm{D}^{\mathrm{NIR}}\right)$ & 0.006 & $0.020 * * *$ & -0.005 \\
\hline 7. & $\mathrm{RR}_{\mathrm{t}-1} \times \mathrm{D}^{\mathrm{NIR}}$ & -0.014 & $0.026 * *$ & -0.003 \\
\hline 8. & Liquidity ratio $_{t-1}$ & 0.027 & 0.012 & -0.013 \\
\hline 9. & Leverage ratio $_{t-1}$ & -0.026 & -0.016 & 0.167 \\
\hline 10. & BLS demand & -0.001 & 0.001 & 0.002 \\
\hline 11. & $r_{t-1}^{L O a n}$ & -0.070 & $-0.155^{* *}$ & -0.151 \\
\hline 12. & Unemployment $_{t-1}$ & -0.080 & $-0.065^{* * *}$ & -0.026 \\
\hline 13. & Constant & 0.001 & 0.007 & 0.007 \\
\hline 14. & Cross section fixed effects & Yes & Yes & Yes \\
\hline 15. & Time fixed effects & Yes & Yes & Yes \\
\hline 16. & Observations & 1,536 & 1,928 & 1,995 \\
\hline 17. & R-Squared & 0.110 & 0.098 & 0.064 \\
\hline 18. & Number of IDs & 59 & 69 & 68 \\
\hline
\end{tabular}

Robust standard errors underneath coefficient estimates.

$* * * \mathrm{p}<0.01, * * \mathrm{p}<0.05, * \mathrm{p}<0.1$

Regressions include cross section and period fixed effects

Table A2-1b: Hypothesis testing

\begin{tabular}{|c|c|c|c|c|}
\hline $\mathrm{HO}$ & & $\begin{array}{c}(1) \\
\text { Low retail }\end{array}$ & $\begin{array}{c}(2) \\
\text { Medium retail }\end{array}$ & $\begin{array}{c}(3) \\
\text { High retail }\end{array}$ \\
\hline \multirow{2}{*}{$\begin{array}{l}\text { 1. EL ratio }{ }_{t-1} \times\left(1-D^{N I R}\right)+ \\
\text { EL ratio }_{t-1} \times\left(1-D^{N I R}\right) \times \\
R_{t-1}=0\end{array}$} & F statistic & \multirow{2}{*}{$\begin{array}{c}3.54 \\
0.0648\end{array}$} & \multirow{2}{*}{$\begin{array}{c}3.97 \\
0.0502\end{array}$} & \multirow{2}{*}{$\begin{array}{c}0.04 \\
0.8440\end{array}$} \\
\hline & p-val (two sided) & & & \\
\hline \multirow{3}{*}{$\begin{array}{l}\text { 2. EL ratio } \text { r }_{-1} \times \mathrm{D}^{\mathrm{NIR}}+ \\
\mathrm{EL} \mathrm{ratio}_{\mathrm{t}-1} \times \mathrm{D}^{\mathrm{NIR}} \times \mathrm{RR}_{\mathrm{t}-1}=0\end{array}$} & F statistic & \multirow{3}{*}{$\begin{array}{c}1.95 \\
0.1684 \\
0.916\end{array}$} & \multirow{3}{*}{$\begin{array}{c}1.33 \\
0.2524 \\
0.126\end{array}$} & \multirow{3}{*}{$\begin{array}{c}7.87 \\
0.0066 \\
0.003\end{array}$} \\
\hline & p-val (two sided) & & & \\
\hline & $\begin{array}{l}\mathrm{p} \text {-val (one- } \\
\text { sided) }\end{array}$ & & & \\
\hline \multirow{3}{*}{$\begin{array}{l}\text { 3. EL ratio } \\
\mathrm{t}-1 \\
\mathrm{EL} \mathrm{ratio}_{\mathrm{t}-1} \times\left(1-\mathrm{D}^{\mathrm{NIR}}\right)+ \\
\left.\mathrm{RR}_{\mathrm{t}-1}=\mathrm{EL} \mathrm{ratio}_{\mathrm{t}-1} \times \mathrm{D}^{\mathrm{NIR}}\right) \times \\
\mathrm{EL} \mathrm{ratio}_{\mathrm{t}-1} \times \mathrm{D}^{\mathrm{NIR}} \times \mathrm{RR}_{\mathrm{t}-1}\end{array}$} & F statistic & \multirow{3}{*}{$\begin{array}{c}0.00 \\
0.9499 \\
0.475\end{array}$} & \multirow{3}{*}{$\begin{array}{c}6.59 \\
0.0124 \\
0.006\end{array}$} & \multirow{3}{*}{$\begin{array}{c}2.92 \\
0.0921 \\
0.046\end{array}$} \\
\hline & p-val (two sided) & & & \\
\hline & p-val (one-sided) & & & \\
\hline
\end{tabular}


Table A2-2a: Effects of NIRP on Domestic Bond Holdings

Dependent variable: Ratio of winsorized flow of domestic sovereign bonds

\begin{tabular}{|c|c|c|c|c|}
\hline & Variables & $\begin{array}{c}(1) \\
\text { Low retail }\end{array}$ & $\begin{array}{c}(2) \\
\text { Medium } \\
\text { retail }\end{array}$ & $\begin{array}{c}(3) \\
\text { High retail }\end{array}$ \\
\hline 1. & Lagged dependent variable & 0.028 & -0.067 & 0.001 \\
\hline 2. & EL ratio $_{t-1} \times\left(1-D^{\mathrm{NIR}}\right)$ & -0.004 & 0.044 & $0.204 * * *$ \\
\hline 3. & $\mathrm{EL}_{\text {ratio }_{\mathrm{t}-1}} \times \mathrm{D}^{\mathrm{NIR}}$ & 0.004 & $-0.084 *$ & 0.091 \\
\hline 4. & $\begin{aligned} \text { EL ratio }_{t-1} \times & \left(1-D^{N I R}\right) \\
& \times R_{t-1}\end{aligned}$ & 0.175 & -0.192 & $-0.232 * *$ \\
\hline 5. & EL ratio $_{t-1} D^{N I R} \times R_{t-1}$ & -0.235 & $0.658 *$ & -0.145 \\
\hline 6. & $\mathrm{RR}_{\mathrm{t}-1} \times\left(1-\mathrm{D}^{\mathrm{NIR}}\right)$ & 0.000 & 0.003 & -0.003 \\
\hline 7. & $\mathrm{RR}_{\mathrm{t}-1} \times \mathrm{D}^{\mathrm{NIR}}$ & 0.005 & -0.014 & -0.011 \\
\hline 8. & Liquidity ratio $_{t-1}$ & -0.005 & $-0.025 * * *$ & $-0.031 * * *$ \\
\hline 9. & Leverage ratio $_{t-1}$ & -0.004 & 0.005 & -0.005 \\
\hline 10. & $r_{t-1}^{\text {Loan }}-r_{t-1}^{10 y}$ & -0.002 & $-0.050 *$ & 0.016 \\
\hline 11. & $\Delta r_{t-1}^{10 y} \times D^{2014}$ & 0.076 & 0.378 & -0.309 \\
\hline 12. & $\log (\text { Assets })_{t-1}$ & -0.166 & $-0.516^{*}$ & 0.104 \\
\hline 13. & Unemployment $_{t-1}$ & 0.018 & $-0.035 *$ & 0.025 \\
\hline 14. & Constant & 0.020 & $0.072 * *$ & -0.000 \\
\hline 15. & Cross section fixed effects & Yes & Yes & Yes \\
\hline 16. & Time fixed effects & Yes & Yes & Yes \\
\hline 17. & Observations & 1,554 & 1,929 & 2,015 \\
\hline 18. & R-Squared & 0.045 & 0.088 & 0.053 \\
\hline 19. & Number of IDs & 59 & 69 & 68 \\
\hline
\end{tabular}

Robust standard errors underneath coefficient estimates.

$* * * p<0.01, * * p<0.05, * p<0.1$

Regressions include cross section and period fixed effects

Table A2-2b: Hypothesis testing

\begin{tabular}{|c|c|c|c|c|}
\hline $\mathrm{HO}$ & & $\begin{array}{c}(1) \\
\text { Low retail }\end{array}$ & $\begin{array}{l}\text { (2) } \\
\text { Medium retail }\end{array}$ & $\begin{array}{c}\text { (3) } \\
\text { High retail }\end{array}$ \\
\hline \multirow{2}{*}{$\begin{array}{l}\text { 1. EL ratio }{ }_{t-1} \times\left(1-D^{N I R}\right)+ \\
\text { EL ratio }_{t-1} \times\left(1-D^{N I R}\right) \times \\
R_{t-1}=0\end{array}$} & F statistic & \multirow{2}{*}{$\begin{array}{c}0.03 \\
0.8741\end{array}$} & \multirow{2}{*}{$\begin{array}{c}0.01 \\
0.9349\end{array}$} & \multirow{2}{*}{$\begin{array}{c}5.00 \\
0.0287\end{array}$} \\
\hline & p-val (two sided) & & & \\
\hline \multirow{3}{*}{$\begin{array}{l}\text { 2. EL ratio } \\
\mathrm{t}-1 \\
\text { EL ratio }_{t-1} \times \mathrm{D}^{\mathrm{NIR}} \times \mathrm{RR}_{\mathrm{t}-1}=0\end{array}$} & F statistic & \multirow{3}{*}{$\begin{array}{c}0.00 \\
0.9929 \\
0.504\end{array}$} & \multirow{3}{*}{$\begin{array}{c}2.61 \\
0.1110 \\
0.056\end{array}$} & \multirow{3}{*}{$\begin{array}{c}0.11 \\
0.7377 \\
0.369\end{array}$} \\
\hline & p-val (two sided) & & & \\
\hline & $\begin{array}{l}\text { p-val (one- } \\
\text { sided) }\end{array}$ & & & \\
\hline \multirow{3}{*}{$\begin{array}{l}\text { 3. EL ratio } \\
\mathrm{t}-1 \\
\mathrm{EL} \mathrm{ratio}_{\mathrm{t}-1} \times\left(1-\mathrm{D}^{\mathrm{NIR}}\right)+ \\
\left.\mathrm{RR}_{\mathrm{t}-1}=\mathrm{EL} \text { ratio }_{\mathrm{t}-1} \times \mathrm{D}^{\mathrm{NIR}}\right) \times \\
\mathrm{EL} \mathrm{ratio}_{\mathrm{t}-1} \times \mathrm{D}^{\mathrm{NIR}} \times \mathrm{RR}_{\mathrm{t}-1}\end{array}$} & F statistic & \multirow{3}{*}{$\begin{array}{c}0.01 \\
0.9095 \\
0.455\end{array}$} & \multirow{3}{*}{$\begin{array}{c}2.43 \\
0.1238 \\
0.062\end{array}$} & \multirow{3}{*}{$\begin{array}{c}4.33 \\
0.0412 \\
0.979\end{array}$} \\
\hline & p-val (two sided) & & & \\
\hline & p-val (one-sided) & & & \\
\hline
\end{tabular}


Table A2-3a: Effects of NIRP on Non-Domestic Bond Holdings

Dependent variable: Ratio of winsorized flow of non-domestic sovereign bonds

\begin{tabular}{|c|c|c|c|c|}
\hline & Variables & $\begin{array}{c}(1) \\
\text { Low retail }\end{array}$ & $\begin{array}{c}(2) \\
\text { Medium } \\
\text { retail }\end{array}$ & $\begin{array}{c}\text { (3) } \\
\text { High retail }\end{array}$ \\
\hline 1. & Lagged dependent variable & -0.101 & 0.052 & 0.096 \\
\hline 2. & EL ratio $_{t-1} \times\left(1-D^{N I R}\right)$ & -0.002 & -0.042 & 0.005 \\
\hline 3. & EL ratio $_{t-1} \times D^{N I R}$ & -0.003 & 0.004 & 0.007 \\
\hline 4. & $\begin{aligned} \text { EL ratio }_{\mathrm{t}-1} \times & \left(1-\mathrm{D}^{\mathrm{NIR}}\right) \\
& \times \mathrm{RR}_{\mathrm{t}-1}\end{aligned}$ & 0.337 & 0.366 & -0.016 \\
\hline 5. & EL ratio $_{t-1} D^{N I R} \times R_{t-1}$ & -0.352 & 0.020 & -0.027 \\
\hline 6. & $\mathrm{RR}_{\mathrm{t}-1} \times\left(1-\mathrm{D}^{\mathrm{NIR}}\right)$ & -0.002 & 0.002 & -0.001 \\
\hline 7. & $\mathrm{RR}_{\mathrm{t}-1} \times \mathrm{D}^{\mathrm{NIR}}$ & -0.006 & $0.009 * *$ & 0.000 \\
\hline 8. & Liquidity ratio $_{\mathrm{t}-1}$ & -0.003 & -0.003 & -0.002 \\
\hline 9. & Leverage ratio $_{t-1}$ & 0.001 & 0.009 & -0.000 \\
\hline 10. & $r_{t-1}^{\text {Loan }}-r_{t-1}^{10 y}$ & 0.002 & -0.007 & $0.027^{*}$ \\
\hline 11. & $\Delta \mathrm{r}_{\mathrm{t}-1}^{10 \mathrm{y}} \times \mathrm{D}^{2014}$ & $0.291 *$ & 0.031 & 0.033 \\
\hline 12. & $\log (\text { Assets })_{t-1}$ & -0.036 & -0.070 & -0.065 \\
\hline 13. & Unemployment $_{t-1}$ & $0.020 *$ & -0.003 & -0.004 \\
\hline 14. & Constant & 0.004 & 0.008 & 0.010 \\
\hline 15. & Cross section fixed effects & Yes & Yes & Yes \\
\hline 16. & Time fixed effects & Yes & Yes & Yes \\
\hline 17. & Observations & 1,554 & 1,929 & 2,015 \\
\hline 18. & R-Squared & 0.065 & 0.038 & 0.042 \\
\hline 19. & Number of IDs & 59 & 69 & 68 \\
\hline
\end{tabular}

Robust standard errors underneath coefficient estimates.

$* * * \mathrm{p}<0.01, * * \mathrm{p}<0.05, * \mathrm{p}<0.1$

Regressions include cross section and period fixed effects

Table A2-3b: Hypothesis testing

\begin{tabular}{|c|c|c|c|c|}
\hline $\mathrm{HO}$ & & $\begin{array}{c}(1) \\
\text { Low retail }\end{array}$ & $\begin{array}{c}\text { (2) } \\
\text { Medium retail }\end{array}$ & $\begin{array}{c}(3) \\
\text { High retail }\end{array}$ \\
\hline \multirow{2}{*}{$\begin{array}{l}\text { 1. } \text { EL ratio }_{\mathrm{t}-1} \times\left(1-\mathrm{D}^{\mathrm{NIR}}\right)+ \\
\mathrm{EL} \mathrm{ratio}_{\mathrm{t}-1} \times\left(1-\mathrm{D}^{\mathrm{NIR}}\right) \times \\
\mathrm{RR}_{\mathrm{t}-1}=0\end{array}$} & F statistic & 1.70 & 1.23 & 0.20 \\
\hline & p-val (two sided) & 0.1971 & 0.2704 & 0.6600 \\
\hline \multirow{3}{*}{$\begin{array}{l}\text { 2. EL ratio } \text { r-1 }_{-1} \times \mathrm{D}^{\mathrm{NIR}}+ \\
\text { EL ratio }_{\mathrm{t}-1} \times \mathrm{D}^{\mathrm{NIR}} \times \mathrm{RR}_{\mathrm{t}-1}=0\end{array}$} & F statistic & 2.69 & 0.91 & 3.58 \\
\hline & p-val (two sided) & 0.1064 & 0.3434 & 0.0629 \\
\hline & $\begin{array}{l}\text { p-val (one- } \\
\text { sided) }\end{array}$ & 0.947 & 0.172 & 0.969 \\
\hline \multirow{3}{*}{$\begin{array}{l}\text { 3. EL ratio } \text { r-1 } \times\left(1-\mathrm{D}^{\mathrm{NIR}}\right)+ \\
\mathrm{EL} \mathrm{ratio}_{\mathrm{t}-1} \times\left(1-\mathrm{D}^{\mathrm{NIR}}\right) \times \\
\mathrm{RR}_{\mathrm{t}-1}=\mathrm{EL} \mathrm{ratio} \mathrm{t}-1 \times \mathrm{D}^{\mathrm{NIR}}+ \\
\mathrm{EL} \mathrm{ratio}_{\mathrm{t}-1} \times \mathrm{D}^{\mathrm{NIR}} \times \mathrm{RR}_{\mathrm{t}-1}\end{array}$} & F statistic & 4.73 & 0.84 & 0.44 \\
\hline & p-val (two sided) & 0.0338 & 0.3619 & 0.5078 \\
\hline & p-val (one-sided) & 0.983 & 0.819 & 0.746 \\
\hline
\end{tabular}


Table A2-4a: Effects of NIRP on Wholesale Funding

Dependent variable: Ratio of winsorized flow of wholesale funding

\begin{tabular}{|c|c|c|c|c|}
\hline \multicolumn{2}{|c|}{ Variables } & $\begin{array}{c}(1) \\
\text { Low retail }\end{array}$ & $\begin{array}{c}(2) \\
\text { Medium } \\
\text { retail }\end{array}$ & $\begin{array}{c}(3) \\
\text { High retail }\end{array}$ \\
\hline 1. & Lagged dependent variable & $-0.145 * * *$ & $-0.078 *$ & -0.004 \\
\hline 2. & EL ratio $_{t-1} \times\left(1-D^{N I R}\right)$ & -0.003 & -0.622 & -0.116 \\
\hline 3. & $\mathrm{EL}_{\text {ratio }_{\mathrm{t}-1}} \times \mathrm{D}^{\mathrm{NIR}}$ & $-0.349 * * *$ & -0.061 & $0.485^{*}$ \\
\hline 4. & $\begin{aligned} \text { EL ratio }_{t-1} \times & \left(1-D^{N I R}\right) \\
& \times R R_{t-1}\end{aligned}$ & $4.241 * *$ & 2.298 & 0.241 \\
\hline 5. & EL ratio $_{t-1} D^{N I R} \times R_{t-1}$ & $3.438 * *$ & 0.207 & $-0.720 * *$ \\
\hline 6. & $\mathrm{RR}_{\mathrm{t}-1} \times\left(1-\mathrm{D}^{\mathrm{NIR}}\right)$ & 0.010 & 0.019 & 0.006 \\
\hline 7. & $\mathrm{RR}_{\mathrm{t}-1} \times \mathrm{D}^{\mathrm{NIR}}$ & -0.096 & $0.039 * *$ & 0.012 \\
\hline 8. & Liquidity ratio $_{t-1}$ & 0.008 & $-0.030 *$ & $-0.035^{* *}$ \\
\hline 9. & Leverage ratio $_{t-1}$ & -0.004 & $0.090 *$ & 0.063 \\
\hline 10. & BLS demand & 0.004 & -0.001 & 0.004 \\
\hline 11. & $r_{t-1}^{2 y}-r_{t-1}^{\text {Deposit }}$ & 0.112 & 0.062 & 0.025 \\
\hline 13. & Unemployment $_{t-1}$ & -0.076 & -0.082 & -0.030 \\
\hline 14. & Constant & -0.001 & 0.014 & 0.008 \\
\hline 15. & Cross section fixed effects & Yes & Yes & Yes \\
\hline 16. & Time fixed effects & Yes & Yes & Yes \\
\hline 17. & Observations & 1,068 & 1,929 & 1,917 \\
\hline 18. & R-Squared & 0.119 & 0.055 & 0.046 \\
\hline 19. & Number of IDs & 50 & 69 & 64 \\
\hline
\end{tabular}

Robust standard errors underneath coefficient estimates.

$* * * \mathrm{p}<0.01, * * \mathrm{p}<0.05, * \mathrm{p}<0.1$

Regressions include cross section and period fixed effects

Table A2-4b: Hypothesis testing

\begin{tabular}{|c|c|c|c|c|}
\hline $\mathrm{H} 0$ & & $\begin{array}{c}\text { (1) } \\
\text { Low retail }\end{array}$ & $\begin{array}{c}\text { (2) } \\
\text { Medium retail }\end{array}$ & $\begin{array}{c}(3) \\
\text { High retail }\end{array}$ \\
\hline \multirow{2}{*}{$\begin{array}{l}\text { 1. } \text { EL ratio }_{\mathrm{t}-1} \times\left(1-\mathrm{D}^{\mathrm{NIR}}\right)+ \\
\mathrm{EL} \mathrm{ratio}_{\mathrm{t}-1} \times\left(1-\mathrm{D}^{\mathrm{NIR}}\right) \times \\
\mathrm{RR}_{\mathrm{t}-1}=0\end{array}$} & F statistic & \multirow{2}{*}{$\begin{array}{c}3.38 \\
0.0722\end{array}$} & \multirow{2}{*}{$\begin{array}{c}1.39 \\
0.2423\end{array}$} & \multirow{2}{*}{$\begin{array}{c}0.04 \\
0.8423\end{array}$} \\
\hline & p-val (two sided) & & & \\
\hline \multirow{3}{*}{$\begin{array}{l}\text { 2. EL ratio }{ }_{t-1} \times D^{N I R}+ \\
\text { EL ratio }_{t-1} \times D^{N I R} \times R_{t-1}=0\end{array}$} & F statistic & \multirow{3}{*}{$\begin{array}{c}7.05 \\
0.0106 \\
0.995\end{array}$} & \multirow{3}{*}{$\begin{array}{c}0.02 \\
0.8876 \\
0.556\end{array}$} & \multirow{3}{*}{$\begin{array}{c}0.69 \\
0.4077 \\
0.204\end{array}$} \\
\hline & p-val (two sided) & & & \\
\hline & $\begin{array}{l}\mathrm{p} \text {-val (one- } \\
\text { sided) }\end{array}$ & & & \\
\hline \multirow{3}{*}{$\begin{array}{l}\text { 3. EL ratio }{ }_{t-1} \times\left(1-D^{N I R}\right)+ \\
\text { EL ratio }_{t-1} \times\left(1-D^{N I R}\right) \times \\
R_{t-1}=E_{L} \text { ratio }{ }_{t-1} \times D^{N I R}+ \\
\text { EL ratio }_{t-1} \times D^{N I R} \times R_{t-1}\end{array}$} & F statistic & \multirow{3}{*}{$\begin{array}{c}11.37 \\
0.0015 \\
0.999\end{array}$} & \multirow{3}{*}{$\begin{array}{c}1.26 \\
0.2661 \\
0.133\end{array}$} & \multirow{3}{*}{$\begin{array}{c}1.63 \\
0.2069 \\
0.103\end{array}$} \\
\hline & p-val (two sided) & & & \\
\hline & p-val (one-sided) & & & \\
\hline
\end{tabular}


Table 13a: Effects of NIRP on Bank Loans for Different Business Models

Dependent variable: Ratio of winsorized loan flow

\begin{tabular}{|c|c|c|c|c|c|c|}
\hline \multicolumn{2}{|r|}{ Variables } & \multirow{2}{*}{$\begin{array}{c}\begin{array}{c}(1) \\
\text { Debt funded } \\
\text { retail }\end{array} \\
0.042\end{array}$} & \multirow{2}{*}{$\begin{array}{c}(2) \\
\begin{array}{c}\text { Diversified } \\
\text { retail }\end{array} \\
0.319^{* * *}\end{array}$} & \multirow{2}{*}{$\begin{array}{c}(3) \\
\begin{array}{c}\text { Focused } \\
\text { retail }\end{array} \\
0.090\end{array}$} & \multirow{2}{*}{$\begin{array}{c}(4) \\
\text { Investment } \\
0.042\end{array}$} & \multirow{2}{*}{$\begin{array}{c}(5) \\
\text { Wholesale } \\
0.025\end{array}$} \\
\hline 1. & $\begin{array}{l}\text { Lagged } \\
\text { variable }\end{array}$ & & & & & \\
\hline 2. & $\begin{array}{r}\text { EL ratio }_{t-1} \times(1 \\
\left.-D^{N I R}\right)\end{array}$ & -0.009 & 0.023 & $-0.060 * * *$ & -0.002 & 0.127 \\
\hline 3. & EL ratio $_{t-1} \times D^{N I R}$ & -0.009 & $-0.064 * * *$ & $-0.100 * * *$ & $-0.037^{* *}$ & 0.034 \\
\hline 4. & $\begin{aligned} \text { EL ratio }_{\mathrm{t}-1} \times( & 1 \\
& \left.-\mathrm{D}^{\mathrm{NIR}}\right) \\
& \times \mathrm{RR}_{\mathrm{t}-1}\end{aligned}$ & $-0.367 * *$ & -0.053 & $0.127 *$ & -0.006 & 1.397 \\
\hline 5. & $\begin{array}{r}\text { EL ratio }_{t-1} D^{N I R} \\
\qquad R_{t-1}\end{array}$ & -0.037 & $0.201 * * *$ & $0.269 * * *$ & 0.167 & 0.322 \\
\hline 6. & $\mathrm{RR}_{\mathrm{t}-1} \times\left(1-\mathrm{D}^{\mathrm{NIR}}\right)$ & 0.004 & 0.004 & $0.017^{* * *}$ & 0.005 & 0.008 \\
\hline 7. & $\mathrm{RR}_{\mathrm{t}-1} \times \mathrm{D}^{\mathrm{NIR}}$ & 0.006 & $0.006 * *$ & $0.021^{* *}$ & 0.002 & 0.008 \\
\hline 8. & Liquidity ratio $_{\mathrm{t}-1}$ & 0.008 & 0.006 & $0.042 * *$ & 0.003 & $0.056 * *$ \\
\hline 9. & Leverage ratio $_{t-1}$ & 0.005 & -0.000 & -0.017 & -0.007 & -0.051 \\
\hline 10. & BLS demand & $-0.004 *$ & -0.000 & 0.003 & 0.002 & 0.004 \\
\hline 11. & $\mathrm{r}_{\mathrm{t}-1}^{\mathrm{Loan}}$ & 0.029 & $-0.111^{* *}$ & $-0.145^{* *}$ & 0.058 & $-0.263^{*}$ \\
\hline 12. & Unemployment $_{t-1}$ & -0.012 & -0.006 & $-0.078 * *$ & $-0.147 * *$ & 0.113 \\
\hline 13. & Constant & -0.001 & 0.002 & 0.002 & $0.010^{*}$ & $-0.039 * *$ \\
\hline 14. & $\begin{array}{l}\text { Cross section fixed } \\
\text { effects }\end{array}$ & Yes & Yes & Yes & Yes & Yes \\
\hline 15. & Time fixed effects & Yes & Yes & Yes & Yes & Yes \\
\hline 16. & Observations & 1,301 & 961 & 2,187 & 264 & 330 \\
\hline 17. & R-Squared & 0.077 & 0.258 & 0.128 & 0.365 & 0.177 \\
\hline 18. & Number of IDs & 48 & 32 & 76 & 9 & 13 \\
\hline
\end{tabular}

Robust standard errors underneath coefficient estimates.

$* * * \mathrm{p}<0.01, * * \mathrm{p}<0.05, * \mathrm{p}<0.1$

Regressions include cross section and period fixed effects 
Table 13b: Hypothesis testing

\begin{tabular}{|c|c|c|c|c|c|c|}
\hline $\mathrm{HO}$ & & $\begin{array}{c}\text { (1) } \\
\text { Debt } \\
\text { funded } \\
\text { retail }\end{array}$ & $\begin{array}{l}(2) \\
\text { Diversified } \\
\text { retail }\end{array}$ & $\begin{array}{l}(3) \\
\text { Focused } \\
\text { retail }\end{array}$ & $\begin{array}{c}\text { (4) } \\
\text { Investment }\end{array}$ & $\begin{array}{c}(5) \\
\text { Wholesale }\end{array}$ \\
\hline \multirow{2}{*}{$\begin{array}{l}\text { 1. EL ratio }{ }_{t-1} \times(1- \\
\left.D^{N I R}\right)+E L \text { ratio } \\
(1-1 \times \\
\left(1-D^{N I R}\right) \times R_{t-1}=0\end{array}$} & F statistic & \multirow{2}{*}{$\begin{array}{c}2.32 \\
0.1347\end{array}$} & \multirow{2}{*}{$\begin{array}{c}0.06 \\
0.8058\end{array}$} & \multirow{2}{*}{$\begin{array}{c}0.38 \\
0.5413\end{array}$} & \multirow{2}{*}{$\begin{array}{c}0.01 \\
0.9318\end{array}$} & \multirow{2}{*}{$\begin{array}{c}1.04 \\
0.3280\end{array}$} \\
\hline & $\begin{array}{c}\text { p-val (two } \\
\text { sided) }\end{array}$ & & & & & \\
\hline \multirow{3}{*}{$\begin{array}{l}\text { 2. EL ratio }{ }_{t-1} \times D^{N I R}+ \\
\text { EL ratio }_{t-1} \times D^{N I R} \times \\
\mathrm{RR}_{\mathrm{t}-1}=0\end{array}$} & F statistic & \multirow{3}{*}{$\begin{array}{c}0.80 \\
0.3748 \\
0.8126\end{array}$} & \multirow{2}{*}{$\begin{array}{c}1.94 \\
0.1732\end{array}$} & \multirow{2}{*}{$\begin{array}{c}0.16 \\
0.6923\end{array}$} & \multirow{2}{*}{$\begin{array}{c}0.79 \\
0.4010\end{array}$} & \multirow{2}{*}{$\begin{array}{c}3.14 \\
0.1016\end{array}$} \\
\hline & $\begin{array}{c}\text { p-val (two } \\
\text { sided) }\end{array}$ & & & & & \\
\hline & $\begin{array}{l}\text { p-val (one- } \\
\text { sided) }\end{array}$ & & 0.0866 & 0.3461 & 0.7995 & 0.0508 \\
\hline \multirow{3}{*}{$\begin{array}{l}\text { 3. EL ratio }{ }_{t-1} \times(1- \\
\left.D^{N I R}\right)+ \text { EL ratio } \\
\left(1-D^{N I R}\right) \times R_{t-1} \times \\
E_{t-1}= \\
E^{N} \text { ratio }_{t-1} \times D^{N I R}+ \\
R_{t-1} \times D^{N I R} \times \\
R_{t}\end{array}$} & F statistic & \multirow{3}{*}{$\begin{array}{c}1.45 \\
0.2347 \\
0.1174\end{array}$} & \multirow{2}{*}{$\begin{array}{c}1.43 \\
0.2411\end{array}$} & \multirow{2}{*}{$\begin{array}{c}0.79 \\
0.3778\end{array}$} & \multirow{2}{*}{$\begin{array}{c}0.15 \\
0.7071\end{array}$} & \multirow{2}{*}{$\begin{array}{c}0.77 \\
0.3982\end{array}$} \\
\hline & $\begin{array}{l}\text { p-val (two } \\
\text { sided) }\end{array}$ & & & & & \\
\hline & $\begin{array}{l}\mathrm{p} \text {-val (one- } \\
\text { sided) }\end{array}$ & & 0.1205 & 0.1889 & 0.6465 & 0.8009 \\
\hline
\end{tabular}

